\title{
Princípios biomecânicos do aparelho extrabucal
}

\author{
Roberto Hideo SHIMIZU*, Aldrieli R. AMBROSIO**, Isabela A. SHIMIZU***, Juliana de GODOY-BEZERRA****,

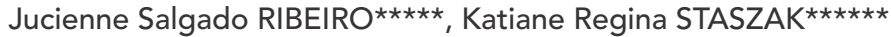

\begin{abstract}
Resumo
A utilização do aparelho extrabucal no tratamento da má oclusão de Classe II de Angle, exige que os princípios biomecânicos sejam entendidos e aplicados para que o caso clínico seja conduzido de maneira que os efeitos colaterais sejam minimizados e os benéficos maximizados. Para tanto, o ortodontista deve ser capaz de prever os efeitos da inclinação da linha de ação de força e sua relação com os centros de resistência da maxila e dos dentes. Quaisquer movimentos de rotação, inclinação ou translação dos dentes, bem como rotação horária ou anti-horária da maxila e da mandíbula, podem ser previstos e planejados quando o ortodontista conhece os mecanismos que os produzem, e também os efeitos que os diferentes tipos de tração produzem em indivíduos dolicofacial, mesofacial ou braquifacial. Assim, o intuito desse trabalho é apresentar fatores preponderantes e imprescindiveis para a utilização do aparelho extrabucal no tratamento da má oclusão de Classe II de Angle.
\end{abstract}

Palavras-chave: Má oclusão Classe II de Angle. Aparelhos de tração extrabucal. Tratamento ortodôntico. Biomecânica.

\section{INTRODUÇÃO}

A má oclusão de Classe II de Angle é caracterizada por uma discrepância maxilo-mandibular dentária e/ou esquelética no sentido ântero-posterior. Essa discrepância pode ser caracterizada por protrusão maxilar, retrusão mandibular ou uma combinação desses fatores. A incidência dessa má oclusão varia de $35 \%$ a $42 \%$, podendo atingir até $50 \%$ dos casos clínicos tratados na clínica ortodôntica $^{35}$. O tratamento deve ser planejado em função das características da má oclusão, ou seja, pelo grau de participação do posicionamento da maxila e/ou da mandíbula especificamente no caso clínico a ser corrigido.

Para a correção da má oclusão de Classe II existem inúmeros aparelhos, dentre eles o aparelho funcional bionator de Balters, o aparelho regulador de Fränkel, o aparelho pêndulo, o pendex e o aparelho extrabucal 1,8,15,19,22,24,26.

O tratamento com aparelho extrabucal restringindo o crescimento anterior da maxila ou redirecionando o crescimento da face está precisamente indicado quando a má oclusão é determinada predominantemente por uma protrusão maxilar $r^{6,11,40,45}$.

* Professor Adjunto Doutor da disciplina de Ortodontia do Curso de Odontologia da PUC-PR, Universidade Tuiuti do Paraná e da EAP/ABO Regional São José dos Pinhais e Cascavel - PR. Mestre e Doutor em Ortodontia pela Faculdade de Odontologia de Araraquara - UNESP.

** Mestranda em Odontologia - Área de Concentração em Ortodontia da PUCPR.

*** Mestre em Ortodontia pela PUCPR. Professora de Ortodontia da EAP/ABO Regional São José dos Pinhais - PR.

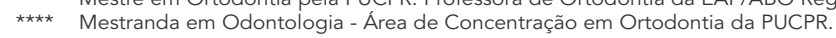

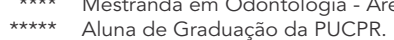

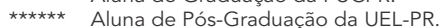


A utilização de tal aparelho requer, dentre outros, conhecimentos biomecânicos necessários para a precisa indicação e monitoração durante o tratamento, o que possibilitaria alcançar, assim, o sucesso do mesmo ${ }^{21,25,34,40}$. Dessa forma, torna-se imprescindível o conhecimento dos conceitos de centros de resistência dos dentes e da maxila e da sua relação com a linha de ação de uma força, determinando-se os centros de rotação dos mesmos ${ }^{40}$.

Blueher ${ }^{11}$ afirmou que com a aplicação dos conhecimentos sobre o crescimento craniofacial e dos conceitos biomecânicos no tratamento dessa má oclusão, é possível conseguir excelentes resultados ortodônticos e/ou ortopédicos utilizando o aparelho extrabucal. Observou ainda que o crescimento craniofacial dos meninos apresenta um maior componente de força anterior do que o das meninas, e por este motivo o tratamento com tração extrabucal deve ser realizado por um maior número de horas por dia em meninos do que em meninas para que o mesmo resultado seja alcançado. Assim, estimando-se a magnitude e direção de crescimento e a intensidade de reação ao tratamento, pode-se determinar se um plano de tratamento específico é compativel com os seus objetivos.

O aparelho extrabucal tem como seus principais efeitos a distalização de molares ${ }^{2}$, restrição do avanço maxilar e redução do overjet ${ }^{6,9,19,43}$.

A tração extrabucal pode ser alta (parietal), média (occipital) ou baixa (cervical), cada uma com suas indicações precisas e resultados programáveis. Ao se modificar o comprimento do arco e sua direção, as conseqüências nas estruturas óssea e dentária são alteradas ${ }^{31}$. Oosthuizen, Dijkman e Evans ${ }^{34}$ realizaram uma avaliação mecânica do aparelho extrabucal com tração cervical e verificaram que ao aumentar o comprimento do arco externo em um lado, o componente de força distal é maior neste. E que inclinando o arco externo para cima o efeito vertical (extrusivo) aumenta. Mas se, independentemente das modificações feitas, a linha de ação de força mantiver as mesmas inclinação e relação com o centro de resistência, o efeito será o mesmo.
Para se optar por uma determinada tração extrabucal, o tipo facial do paciente deve ser considerado. Pois cada um deles tem um padrão de crescimento e desenvolvimento próprio, e o resultado obtido por diferentes trações de força extrabucais pode ser previsto e programado ${ }^{7,10,14}$.

Uma tração extrabucal comumente utilizada por obter ótimos resultados de retrusão maxilar e distalização do molar superior é a baixa ou cervi$\mathrm{cal}^{8,11,12}$. Suas conseqüências sobre o crescimento vertical e a inclinação do plano mandibular são fatores a serem ponderados na decisão de utilizá-la ou não em pacientes dolicofaciais. A tração baixa tende a extruir os molares, rotacionar a mandíbula no sentido horário e a aumentar o terço inferior da face $4,7,11,12,14,29,33,40,44$.

A tração horizontal ou occipital diminui a possibilidade de extrusão dos molares e os distaliza sem alterar a altura facial inferior do paciente ${ }^{29}$. Ela é caracterizada pela linha de ação de força direcionada para a região occipital, e, portanto, é mais fácil obter o paralelismo da linha de ação de força com o plano oclusal e, assim, anular ou minimizar o componente de força intrusivo ou extrusi$\mathrm{vo}^{34}$. Entretanto, alguma rotação pode ocorrer, mas em menor intensidade do que nos outros tipos de tração. Observa-se também a restrição do deslocamento anterior da maxila com essa tração $0^{33}$.

Quando a tração alta ou parietal é a opção de tratamento, observa-se que ela restringe o crescimento vertical indesejável, não aumentando a altura facial anterior e podendo inclusive intruir molares ${ }^{12,28,44}$. A tração alta é direcionada para a região parietal, e por isso o componente intrusivo sempre está presente ${ }^{34}$. Teuscher ${ }^{40}$ observou que a tração alta minimiza as rotações posteriores pelo controle mais efetivo do crescimento. Embora Langlade $^{29}$ tenha afirmado que a distalização do molar nesse tipo de tração é quase nula, Üçem e Yüksel ${ }^{44}$ confirmaram a capacidade de distalização desse dente.

É bastante comum a observação de movimentos de rotação da mandíbula durante a utilização 
de aparelho extrabucal. De acordo com Schudy ${ }^{38}$, as rotações ocorrem quando o crescimento na região condilar difere do crescimento vertical na região de molares. Se este último for maior, essa variação pode causar rotação horária, provocando a abertura de mordida. A quantidade e a direção de crescimento podem ser obtidas pela correta indicação do tipo de tração extrabucal, que estimule ou não o crescimento na região de molares.

Importante ressaltar ainda que a idade esquelética do paciente é de extrema relevância para a excelência da correção dessa má oclusão, pois o tratamento durante a fase do surto de crescimento puberal permite, em algumas situações, a harmonização da discrepância esquelética, a diminuição da necessidade de extrações e também a redução do tempo de tratamento ${ }^{28}$. A estabilidade dessas mudanças também deve ser observada, de acordo com Wieslander e Buck ${ }^{46}$, que observaram mínima recidiva em estruturas faciais, molares superiores e base da maxila após seis anos de acompanhamento após o tratamento com tração baixa em crianças com má oclusão de Classe II de Angle.

Portanto, objetivou-se com este trabalho, apresentar os aspectos biomecânicos necessários para a utilização do aparelho extrabucal e conseqüentemente, otimização do tratamento das más oclusões Classe II de Angle.

\section{DISCUSSÃO}

\section{Filosofias de tratamento da má oclusão Classe II de Angle}

Para que se obtenha a correção de uma má oclusão de Classe II de Angle, diferentes aparelhos e/ou filosofias podem ser utilizados. Dentre eles, podemos citar os aparelhos funcionais bionator de Balters e o regulador de Fränkel $15,22,26,45$, o aparelho extrabucal ${ }^{26,33,45}$ e o aparelho pêndulo ${ }^{24}$.

As estratégias para a correção dessa má oclusão variam. Harvold e Vargervik ${ }^{22}$, relacionaram cinco hipóteses para o tratamento da má oclusão Classe II de Angle: maior crescimento mandibular, mesialização dos dentes posteriores inferiores, restrição do crescimento maxilar, distalização dos dentes superiores e um grande aumento na altura do processo alveolar mandibular em relação ao maxilar.

O aparelho funcional, que é uma alternativa para a correção da má oclusão Classe II de Angle, atua restringindo o crescimento anterior da maxila ${ }^{19,26} \mathrm{e}$ estimulando o aumento da altura do processo alveolar mandibular resultando em aumento de altura inferior da face ${ }^{22}$. A resposta obtida com o aparelho funcional é uma protrusão mandibular ${ }^{19,42}$ e aumento do comprimento da mandíbula ${ }^{19}$. Baumrind et al. ${ }^{7}$ confirmaram em seu estudo que o crescimento efetivo da mandíbula (côndilo-pogônio) é maior nos pacientes que utilizaram o aparelho funcional.

Segundo Baumrind et al. ${ }^{8}$, quando comparado ao aparelho extrabucal, os resultados obtidos com o aparelho funcional representaram $1 / 3$ daqueles alcançados com o aparelho extrabucal. Wheeler et al. ${ }^{45}$ também concordaram sobre o tratamento com o aparelho extrabucal ser mais eficaz, tendo verificado duas vezes mais sucesso no tratamento com este aparelho do que aquele realizado com aparelho funcional. A restrição do avanço ortopédico maxilar no tratamento com aparelho funcional é maior do que a observada em um grupo que não tenha recebido tratamento, mas menor do que naqueles que tenham utilizado o aparelho extrabucal. Confirmando sua eficiência até mesmo para casos clínicos mais complexos, DeVincenzo e Winn ${ }^{15}$ preconizaram o tratamento com aparelho extrabucal para os pacientes que não obtiveram resultados satisfatórios com o aparelho funcional.

O aparelho pêndulo, demonstrado no estudo de Hilgers ${ }^{24}$, mostra-se contra-indicado para indivíduos dolicofaciais, devido à tendência de abrir a mordida, indicando-se, portanto o tratamento com aparelho extrabucal. Enfim, o tratamento com aparelho extrabucal, é uma alternativa muito comum e com resultados altamente favoráveis na correção da má oclusão de Classe II de Angle.

\section{Época ideal para o tratamento}

O tratamento ortodôntico da má oclusão Classe II 
é freqüentemente dividido em três fases: precoce, na dentadura mista; abrangente, na permanente; e contenção, após o tratamento ${ }^{42}$. No entanto, são comuns as investigações para avaliar a validade da intervenção precoce e qual é o momento correto para se iniciar o tratamento. Tulloch et al. ${ }^{42}$ colocaram em discussão o fato de que aos 16 anos de idade fica impossível distinguir quais crianças receberam tratamento precoce dentre aquelas em que o tratamento ocorreu mais tardiamente. Para Kloehn ${ }^{27}$, a intervenção com forças extrabucais deve ser o mais precoce possível, logo após a irrupção dos primeiros molares permanentes pois, dessa forma, haverá uma diminuição gradual do crescimento da maxila e dos processos alveolares. Ghafari et al. ${ }^{19}$ indicaram como momento ideal para iniciar o tratamento o final da infância, imediatamente antes da perda dos segundos molares superiores decíduos, pois reduz o número de visitas ao dentista, reduz os custos e é mais prático. Para Baptista ${ }^{5}$ a melhor idade para o emprego de forças extrabucais capazes de produzir alterações esqueléticas vai de 8 anos e 6 meses a 10 anos e 6 meses para o gênero feminino e, para o gênero masculino, de 9 anos e 6 meses a 11 anos e 6 meses.

Um fator a ser considerado para a determinação do momento ideal de tratamento é a idade esquelética que indica o surto de crescimento puberal. Para se determinar a idade esquelética, utiliza-se as radiografias de mão e punho ${ }^{19,28,43}$. Kopecky e Fishman ${ }^{28}$ realizaram um estudo sobre o momento correto para o tratamento com o aparelho extrabucal. A idade de maturação foi estabelecida por meio de radiografias de mão e punho, e de acordo com o período do desenvolvimento em que a criança se encontra é possivel prever os resultados sobre as estruturas maxilares. Os estágios de maturação óssea são de 1 a 8 , e são determinados pelo desenvolvimento sinfisário. Nos estágios de 4 a 7 a maturação ocorre no dobro da velocidade dos estágios 1 a 3. Essas diferenças de maturação refletem nas respostas observadas durante o tratamento com o aparelho extrabucal.

Tulloch et $a 1 .{ }^{42}$ não notaram correlação entre a idade e maturidade com a magnitude da resposta do tratamento, porém não consideraram a severidade do problema esquelético inicial, o padrão de crescimento antes e durante o tratamento e a cooperação do paciente com a magnitude da resposta.

Poder-se-á obter bons resultados no tratamento da má oclusão Classe II de Angle quando o emprego de forças extrabucais for iniciado de 6 meses a 1 ano antes do início do surto de crescimento puberal, para que o restabelecimento parcial ou total da harmonia esquelética maxilo-mandibular preceda o tratamento ortodôntico corretivo. Outra opção seria iniciar o tratamento com AEB (aparelho extrabucal) juntamente com a Ortodontia corretiva no início do surto de crescimento, desde que a discrepância esquelética não seja muito severa, para que a correção dessa displasia seja realizada adequada e simultaneamente com o tratamento ortodôntico corretivo. Esses procedimentos diminuem o tempo total de tratamento, bem como reduzem as possibilidades de extrações dentárias para a resolução da má oclusão. A utilização muito precoce do AEB tendo o primeiro molar como ancoragem, proporciona grande movimentação dentária deste, porém aumenta a possibilidade de impactação do segundo molar permanente.

\section{Avaliação do padrão de crescimento}

$O$ padrão de crescimento craniofacial pode ser avaliado por meio do estudo cefalométrico. Grandezas cefalométricas como o SN.GoGn e o FMA são excelentes referenciais para determinar o padrão de crescimento do indivíduo e assim, classificá-lo como dolicofacial, mesofacial ou braquifacial. O conhecimento do padrão de crescimento do paciente permite planejar qual sistema de forças é adequado para proporcionar a correção dentoesquelética e, conseqüentemente, uma face harmoniosa. A grandeza cefalométrica FMA apresenta um valor médio de $25^{\circ}\left( \pm 4^{\circ}\right)$ para indivíduos mesofaciais, quanto maior esta grandeza, maior a tendência a um crescimento vertical e, portanto, dolicofacial. Da mesma forma, quanto menor, mais horizontal será o cres- 
cimento (braquifacial). A grandeza cefalométrica SN.GoGn tem valor médio de $32^{\circ}\left( \pm 2^{\circ}\right)$, e sua avaliação é feita da mesma maneira que aquela para o FMA, ou seja, valores acima dessa variação sugerem padrão dolicofacial e abaixo, braquifacial.

Os indivíduos dolicofaciais têm padrão de crescimento vertical, portanto, nesses indivíduos a extrusão dos molares provoca maior inclinação do plano mandibular, acentua o padrão de crescimento vertical e favorece a abertura da mordida. Como a extrusão é provocada pelo uso da tração baixa, fica esta contraindicada para indivíduos dolicofaciais ${ }^{7,11,33}$. Segundo Barton $^{4}$, a correção da má oclusão de Classe II é mais difícil para os indivíduos dolicofaciais.

A utilização da tração horizontal torna-se uma opção de uso interessante, uma vez que proporciona maior controle aos movimentos extrusivos e intrusivos, bem como promove mais facilmente o movimento de translação do dente de suporte ${ }^{19,33}$. $\mathrm{E}$, de acordo com Barton ${ }^{4}$ possui maior componente de força horizontal (distal) do que a tração alta.

Em indivíduos braquifaciais o aparelho extrabucal com tração alta ou parietal não é muito adequado por causar rotação anti-horária da mandíbula, acentuando a sobremordida ${ }^{38}$. Para esses indivíduos, pode-se utilizar a tração cervical, pois apresentam um crescimento predominantemente horizontal.

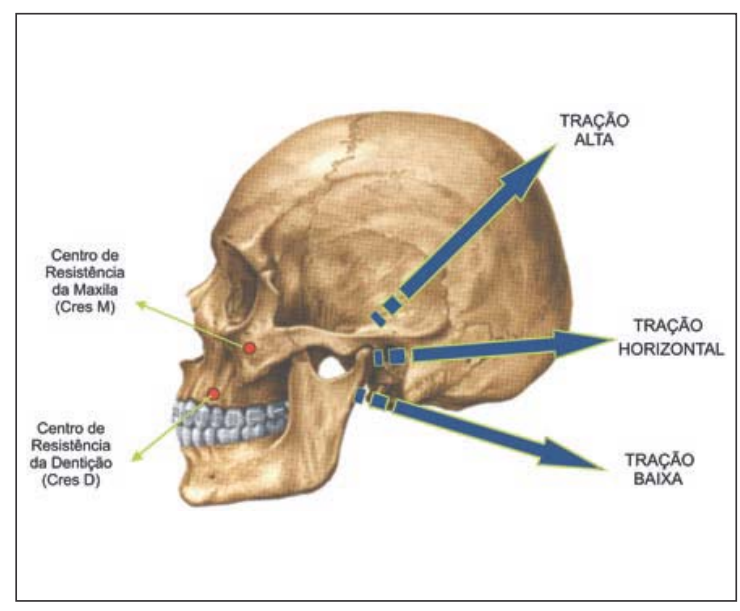

FIGURA 1A - Tipos de tração extrabucal: alta, horizontal e baixa.
A extrusão, quando ocorrer, não será capaz de aumentar excessivamente a altura facial anterior, permitindo que resultados favoráveis sejam alcançados sem que a estética facial seja afetada ${ }^{12}$. Importante ressaltar que a tração baixa, eventualmente também pode ser utilizada por indivíduos mesofaciais, com resultados bastante satisfatórios, além do que o aparelho com essa característica é mais facilmente aceito por ser mais estético e confortável.

\section{Tipos de tração ou puxada}

Uma vez que os indivíduos podem apresentar um padrão de crescimento predominantemente vertical, equilibrado ou horizontal, ou seja, dolicofacial, mesofacial ou braquifacial, três diferentes tipos de tração extrabucal podem ser empregados. Os tipos de tração são: alta ou parietal, horizontal ou occipital e baixa ou cervical ${ }^{4,25,34}$, conforme ilustrados na figura 1A. Portanto, a necessidade de compreender a utilização e os efeitos de cada tipo de tração deve ser enfatizada.

O aparelho extrabucal pode ser utilizado com o arco externo inclinado para baixo, para cima ou paralelo ao plano oclusal e, ainda, curto, médio e longo (Fig. 1B).

A tração baixa ou cervical tende a direcionar o crescimento da maxila e da mandíbula mais inferior e

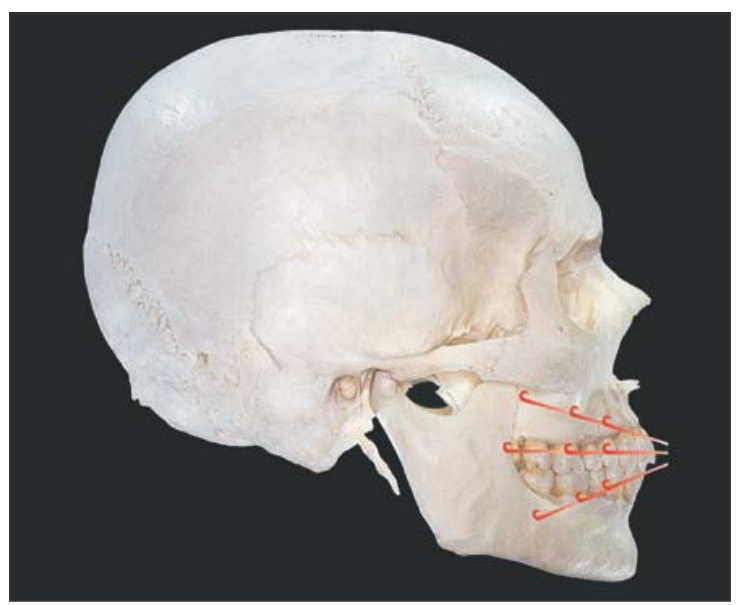

FIGURA 1B - Combinações de diferentes comprimentos e inclinações do arco externo do arco facial. 
posteriormente $11,12,33,40,43$, a retruir o ponto $\mathrm{A}^{11,12,33,46}$ e a extruir os molares superiores, $4,12,19,25,31,33,34,44$.

Verifica-se também um aumento na altura facial ântero-inferior e do ângulo do plano mandibular ${ }^{12}$. Esses resultados, segundo Blueher ${ }^{11}$, podem ser observados em praticamente $50 \%$ dos casos tratados com a tração baixa. Com esta, o plano oclusal funcional inclina inferior e posteriormente ${ }^{12}$ e o plano palatino eleva-se na região posterior do palato $^{8}$. Observa-se também um grande crescimento efetivo da mandíbula (côndilo-pogônio), comparável ao obtido pelo tratamento com aparelho funcional, e superior ao crescimento naqueles indivíduos sem tratamento ou tratados utilizandose tração $\mathrm{alta}^{7}$. O aumento da altura do ramo da mandíbula (côndilo-gônio) foi maior quando utilizada a tração cervical, em comparação à tração alta e a nenhum tratamento ${ }^{7}$.

A utilização da tração baixa na distalização do molar deverá provocar, além do seu movimento distal propriamente dito, extrusão com inclinação provocando a rotação horária da mandíbula. $\mathrm{O}$ movimento extrusivo será maior quanto mais curto for o arco externo. Considerando uma extrusão

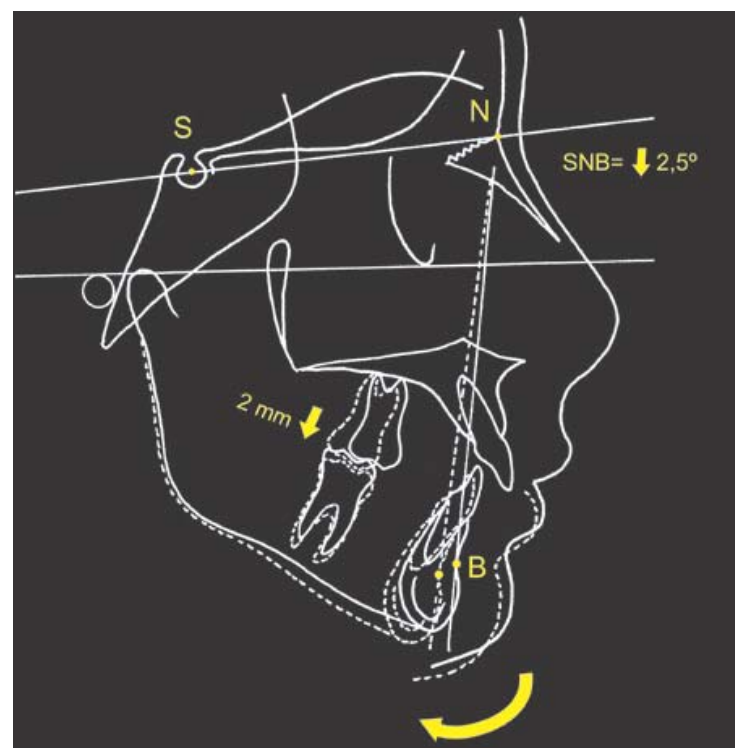

FIGURA 2 - Efeito de rotação horária da mandíbula provocado pela extrusão de $2,0 \mathrm{~mm}$ do molar superior durante a utilização do AEB com tração baixa. de 2,0 $\mathrm{mm}$ do primeiro molar superior, a grandeza cefalométrica SNB diminuirá aproximadamente $2,5^{\circ}$ (Fig. 2). Como conseqüência da utilização da tração baixa, deverá ocorrer a correção da relação molar de Classe II, entretanto haverá uma maior dificuldade na correção da discrepância esquelética maxilo-mandibular, pois o ponto B será reposicionado para baixo e para trás com a rotação horária da mandíbula. Essa rotação também é desfavorável para o perfil inferior e total da face.

Utilizando a tração baixa, sempre ocorrerá extrusão dos molares. A resultante da movimentação da dentição em um indivíduo utilizando aparelho extrabucal com tração baixa, considerando o crescimento e a reação ao movimento dentário e maxilar, pode ser visualizada na figura 3. A diferença é observada nas seguintes situações: quando o arco externo está inclinado para baixo, o principal movimento é de distalização, com forte inclinação da coroa para distal, e, quando inclinado para cima, conforme o grau dessa inclinação, o dente extrui e inclina a raiz para distal ${ }^{29,31}$, como pode ser verificado na figura 4.

Segundo Melsen ${ }^{31}$, quando o arco externo está inclinado para cima, os movimentos dentários são

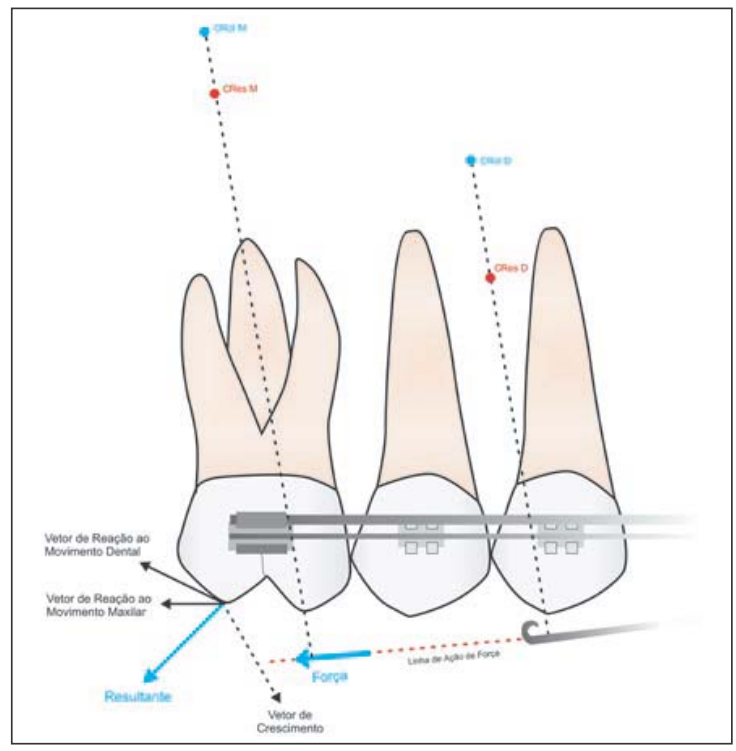

FIGURA 3 - Resultante da movimentação da dentição, considerando os vetores de reação aos movimentos dental e maxilar, utilizando AEB com tração baixa (adaptação de Teuscher, 1986). 
menores, mas não há tanta inclinação e se obtém maior restrição do crescimento ântero-posterior da maxila. A média de movimento distal do molar superior obtida foi de $3,5 \mathrm{~mm}$, sendo esse movimento avaliado por meio de implantes posicionados na maxila. Essa metodologia avalia com maior precisão o movimento distal do molar, pois os referenciais estão na própria estrutura maxilar.

Um ponto desfavorável na utilização da tração baixa é a forte inclinação produzida no dente suporte, uma vez que dentes inclinados tendem a se verticalizar no período pós-tratamento de acordo com a posição do ápice de suas raízes. Assim, algum grau de recidiva poderá ser verificado e, portanto, deverá ser realizada uma pequena sobrecorreção da relação molar.

Os efeitos nos molares utilizados para ancoragem do aparelho extrabucal, com as mesmas combinações de ajustes do arco externo realizadas para a tração baixa, podem ser verificados nas figuras 5 e 6, para as trações horizontal e alta, res- pectivamente. A tração alta ou parietal acentua a irrupção dos molares inferiores, segundo Brown ${ }^{12}$, que afirmou ainda não existir uma tendência significante do ponto A ser posicionado para trás e da altura facial ântero-inferior aumentar. Verificou ainda, que com a utilização da tração alta, a redução do ângulo ANB não foi tão efetiva quanto aquela com a utilização da tração baixa, e que, quanto ao plano oclusal funcional, este não sofreu alteração. Barton ${ }^{4}$ verificou que a tração alta pode não exercer a força horizontal necessária para posteriormente retrair incisivos em severas protrusões, sendo nestes casos necessário indicar a tração média. No entanto, Baumrind et al. ${ }^{8}$ relataram que o tratamento com a tração alta obtém resultados mais rapidamente, porém requer um maior período de controle pós-tratamento, durante o qual o crescimento residual pode ocorrer e prejudicar os resultados obtidos com o tratamento. Afirmaram ainda que a distalização do molar superior, quando utilizaram a tração alta, foi maior

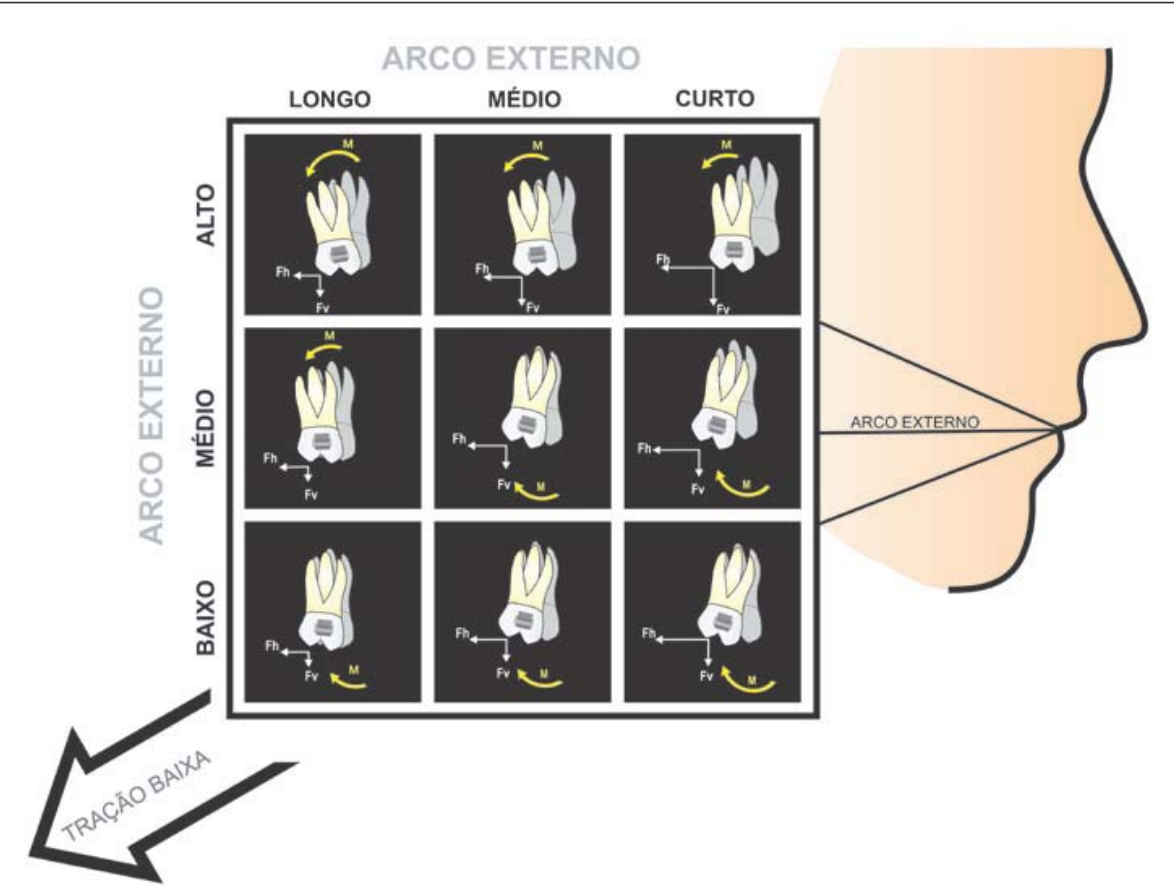

FIGURA 4 - Efeito produzido no molar pela combinação de diferentes comprimentos e inclinações do arco externo do aparelho extrabucal utilizando-se a tração baixa (adaptação de Langlade, 1993). 


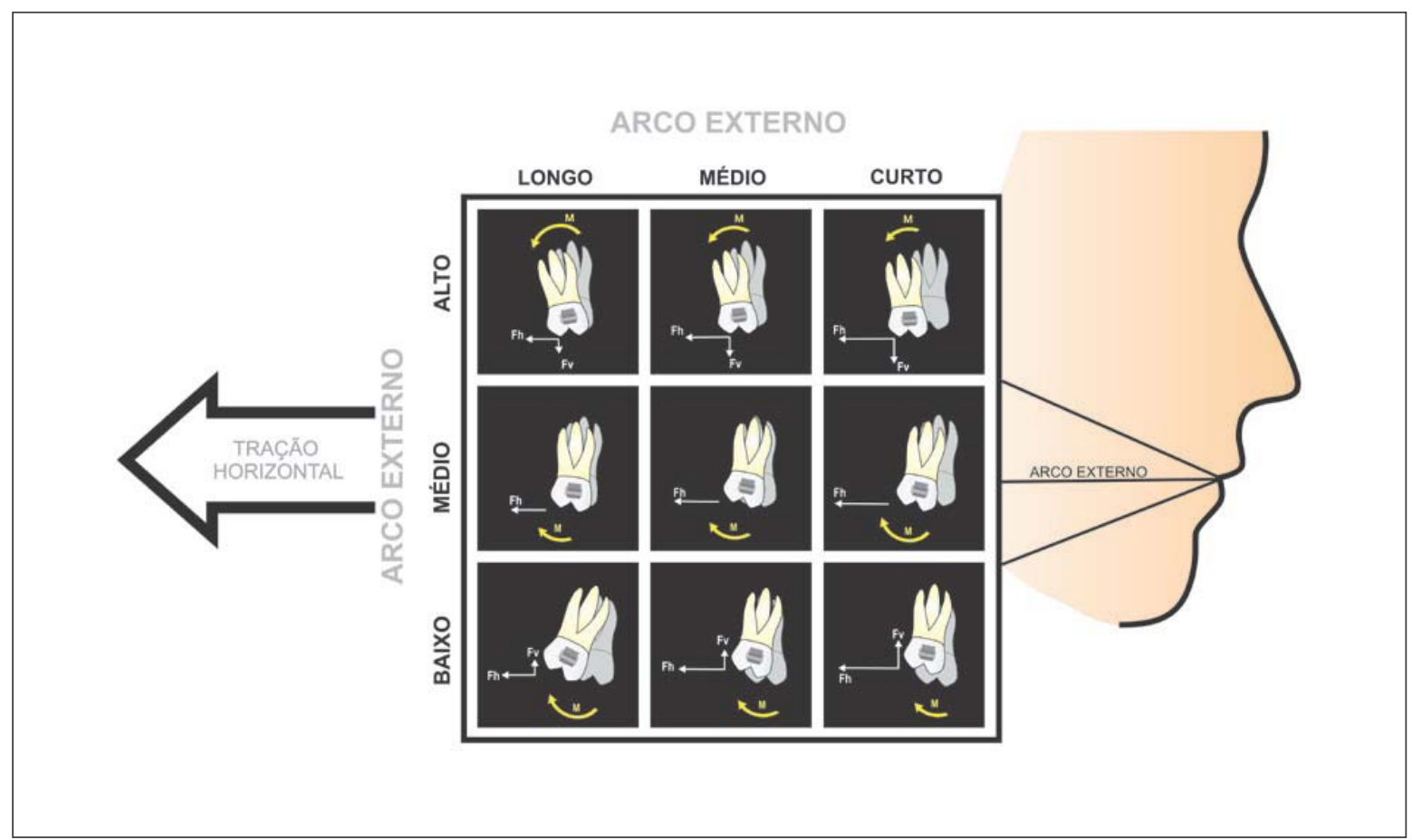

FIGURA 5 - Efeito produzido no molar pela combinação de diferentes comprimentos e inclinações do arco externo do aparelho extrabucal utilizando-se a tração horizontal (adaptação de Langlade, 1986).

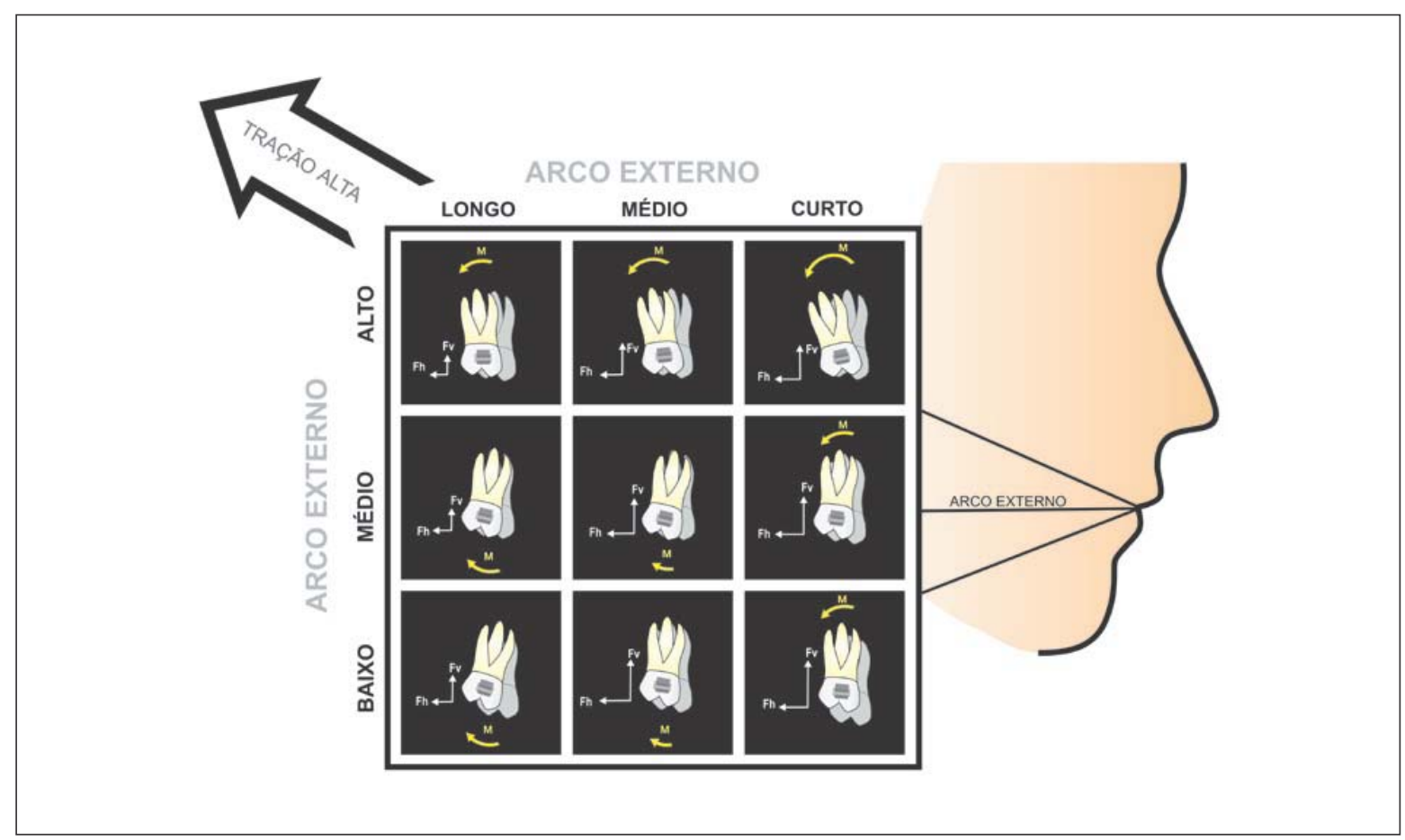

FIGURA 6 - Efeito produzido no molar pela combinação de diferentes comprimentos e inclinações do arco externo do aparelho extrabucal utilizando-se a tração alta (adaptação de Langlade, 1986). 
do que aquela obtida com a tração baixa. Da mesma maneira, a inclinação distal da coroa também foi maior com a puxada alta quando comparada com a baixa. O plano palatino tendeu a aumentar a inclinação, elevando-se na região posterior do palato, sendo este um mecanismo diferente do que ocorre na tração baixa, quando a região anterior se movimenta inferiormente ${ }^{8}$.

Teuscher ${ }^{40}$ observou que a tração alta minimiza as rotações posteriores pelo controle mais efetivo do crescimento. Isso ocorre porque a puxada alta ou parietal comprime as três suturas primárias da maxila, que são a zigomaticomaxilar, a frontomaxilar e a pterigopalatina. $\mathrm{O}$ autor notou diferenças interessantes entre a aplicação da linha de ação da força mais anterior ou posteriormente durante o tratamento com tração alta. Quando a linha de ação da força se localizava mais anteriormente notou-se rotação anterior da dentição, sem nenhum controle vertical dos molares e acentuado controle dos incisivos e quase sem nenhum efeito distal nos dentes superiores. Quando a localização da linha de ação de força era mais posterior, verificou rotação posterior da dentição, acentuado controle vertical na região dos molares e pouco na região de

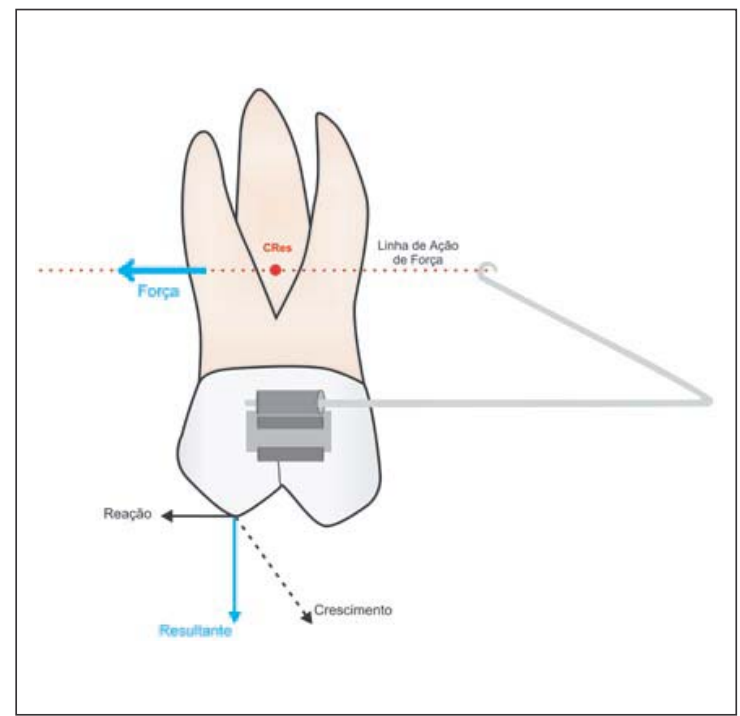

FIGURA 7 - Interação dos fatores a serem considerados na utilização do AEB (adaptação de Teuscher, 1986). incisivos e consideráveis efeitos distais nos dentes superiores.

Avaliando a utilização do AEB com tração alta, Langlade ${ }^{29}$ citou como principais efeitos: intrusão dos molares superiores, que aumenta com o encurtamento do arco externo e sua orientação para baixo; pouca distalização do molar; reorientação da direção do crescimento da maxila; rotação antihorária da mandíbula e aumento da ancoragem do molar superior.

Em relação à utilização de forças extrabucais combinadas (tração alta e baixa), Langlade ${ }^{29}$ afirmou que o movimento distal dos primeiros molares superiores pode ser realizado por translação se a intensidade da força vertical for maior que a força cervical. Conforme a combinação de forças verticais e cervicais, pode-se verificar intrusão do molar superior, rotação horária da maxila e diminuição da convexidade facial por modificação favorável das relações das bases ósseas maxilo-mandibulares.

Üçem e Yüksel ${ }^{44}$ realizaram um estudo em que o aparelho extrabucal combinava a tração baixa à alta. Foram criados três grupos, nos quais o mesmo aparelho era utilizado. No entanto, a magnitude

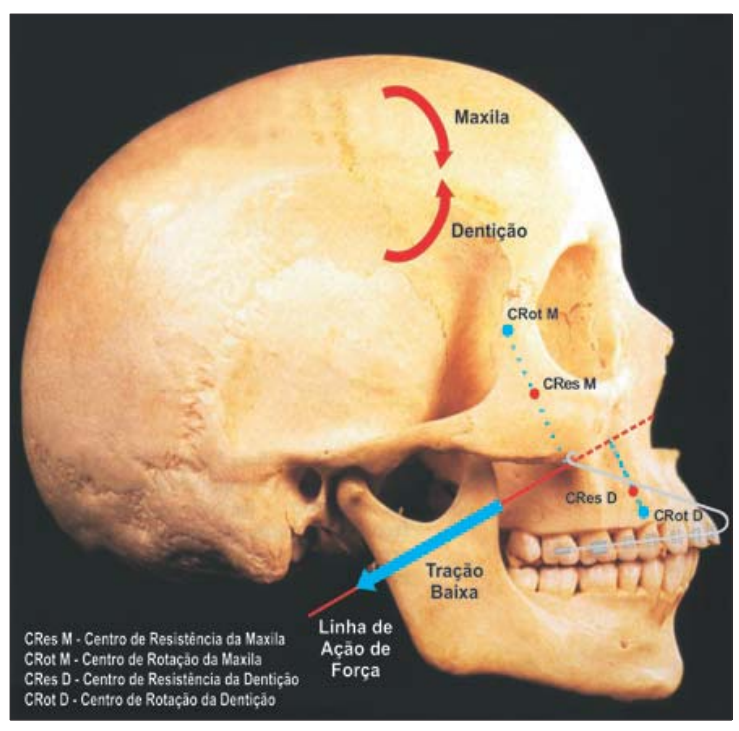

FIGURA 8 - Demonstra a linha de ação de força passando entre o CResM e o CResD e os seus efeitos de rotação, quando é utilizada uma tração baixa (adaptação de Teuscher, 1986). 
de força variava, ora predominando a tração baixa, ora a alta ou apresentava iguais magnitudes. Quando apresentou maior magnitude de força para a tração alta, o movimento de translação do molar foi maior e o ângulo SN.GoGn diminuiu. A distalização do molar acompanhada de uma forte inclinação foi maior e a distância intercaninos foi aumentada no grupo com maior magnitude de força para a tração baixa.

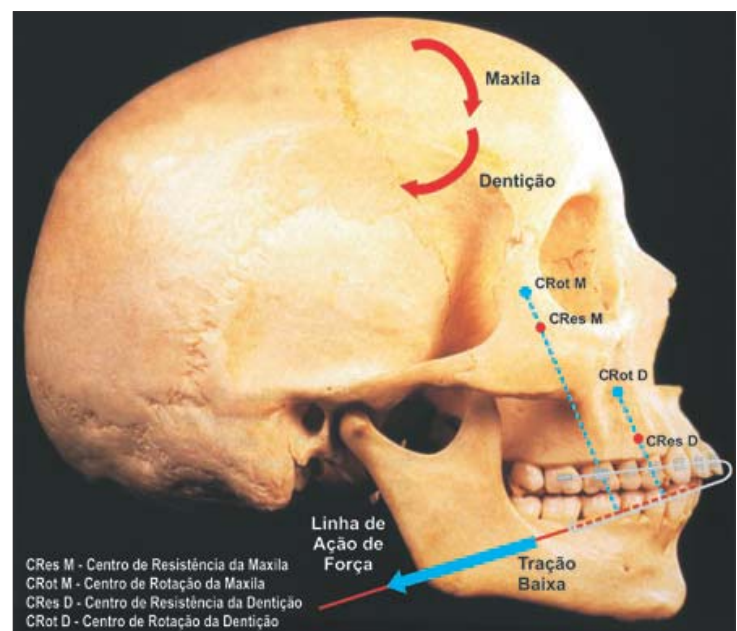

FIGURA 9 - Demonstra a linha de ação de força passando abaixo do CResM e do CResD e a rotação horária que ocorre na maxila e nos dentes, quando é utilizada uma tração baixa (adaptação de Teuscher, 1986).

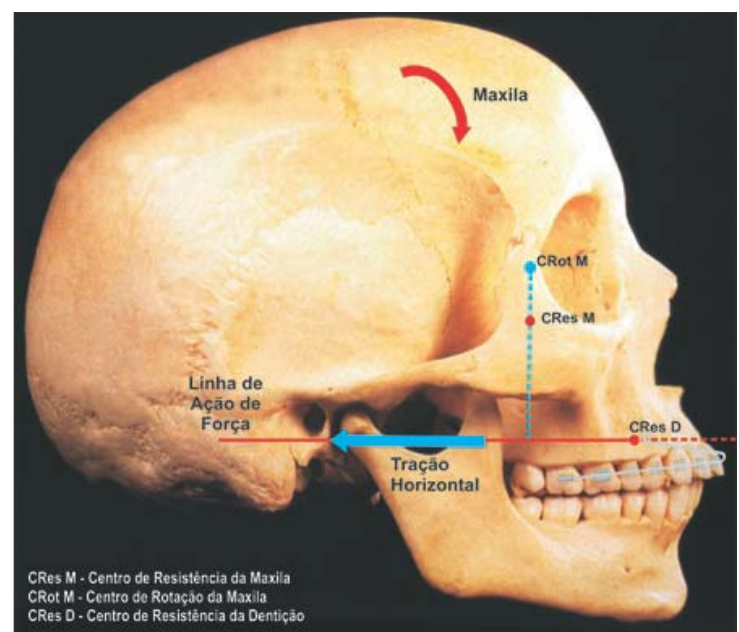

FIGURA 11 - Demonstra a linha de ação de força coincidente com o CResD (ausência de rotação da dentição) e a rotação horária que ocorre na maxila, quando é utilizada uma tração horizontal.

\section{Conceitos biomecânicos aplicados à utilização do aparelho extrabucal}

Para que o tratamento da má oclusão Classe II seja realizado com sucesso, é imprescindivel que se conheça todos os componentes e as variações programáveis durante a utilização do aparelho extrabucal. Os componentes são: o arco interno, que, geralmente, se encaixa à banda do dente a ser distalizado; o molar e o arco externo, no qual se ancora

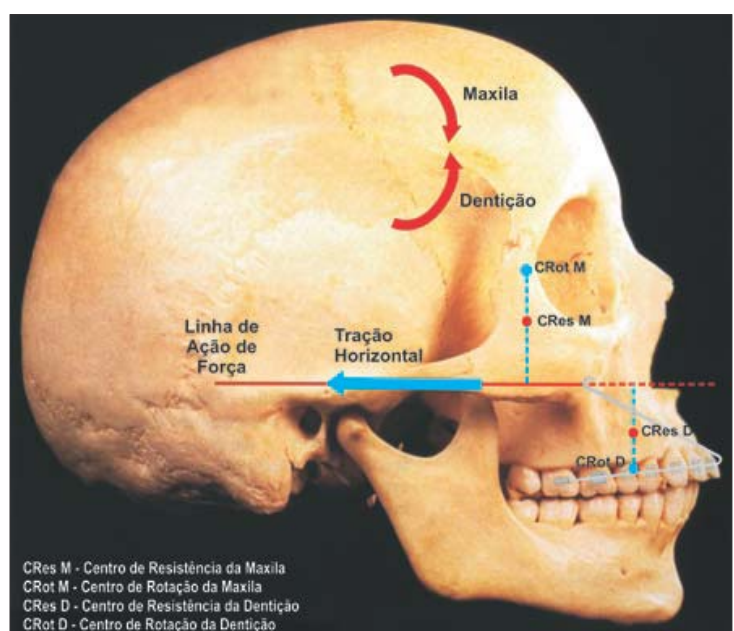

FIGURA 10 - Demonstra a linha de ação de força passando entre o CResM e o CResD e as rotações horária na maxila e anti-horária nos dentes, quando é utilizada uma tração horizontal.

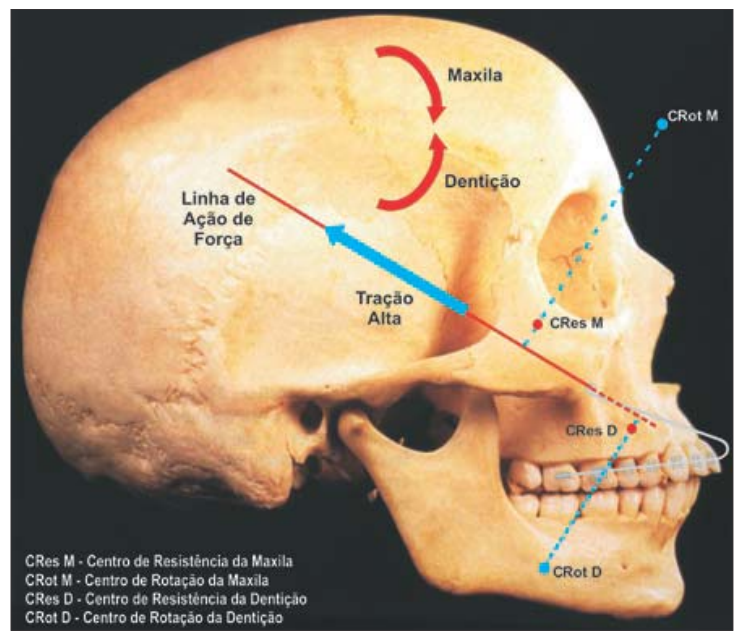

FIGURA 12 - Demonstra a linha de ação de força passando entre o CResM e o CResD e as rotações horária na maxila e anti-horária nos dentes, quando é utilizada uma tração alta (adaptação de Teuscher, 1986). 


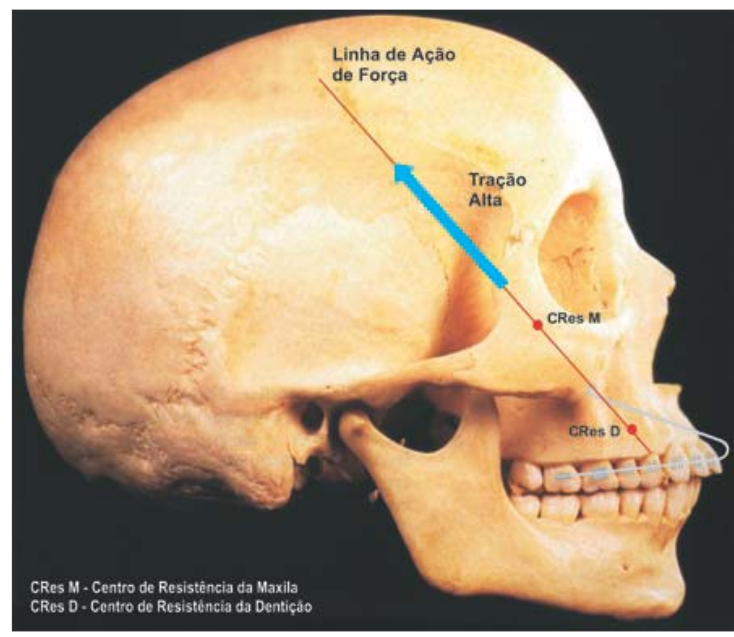

FIGURA 13 - Demonstra a coincidência da linha de ação de força com o CResM e o CResD e a ausência de rotações dessas estruturas, utilizando-se uma tração alta (adaptação de Teuscher, 1986).

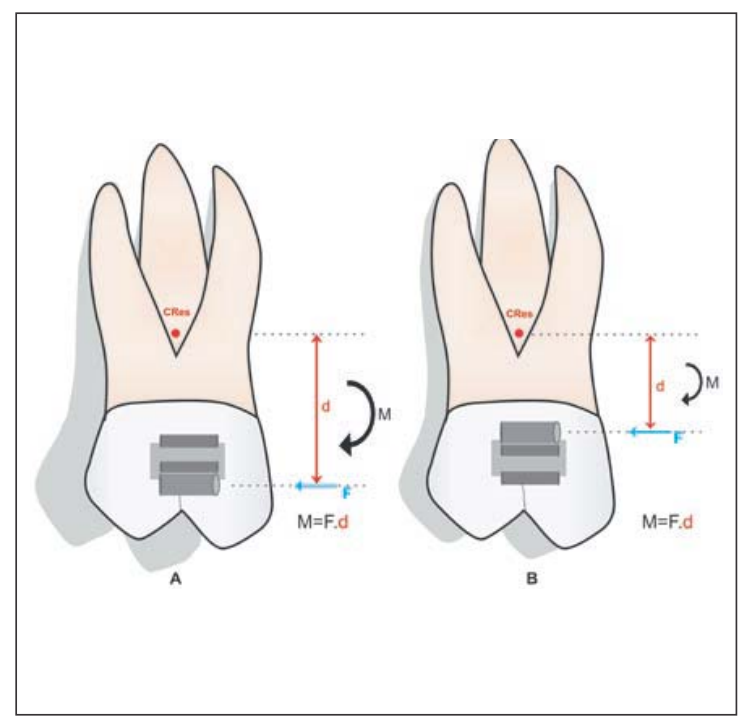

FIGURA 15 - Redução do momento gerado pela diminuição da distância entre o CRes do molar e a linha de ação de força, pela inversão da posição do tubo onde se insere 0 arco interno do aparelho extrabucal, posicionado oclusal (A) e cervicalmente (B)

a tração. $\mathrm{O}$ arco externo, pode ser curto, médio ou longo e ainda, estar posicionado horizontalmente, inclinado para baixo ou para cima $25,29,34$, como pode ser visualizado na figura 1B. O ajuste desses componentes é realizado considerando fatores como: os centros de resistência da maxila (CResM) e da den-

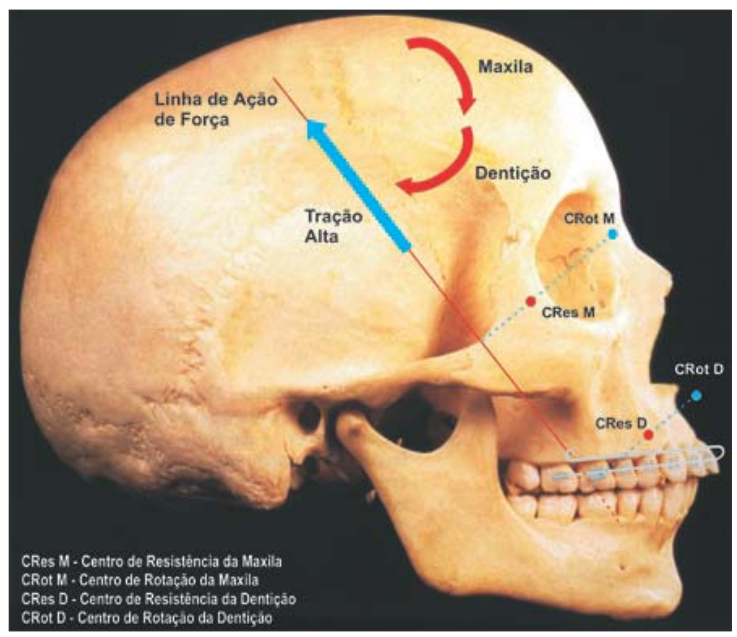

FIGURA 14 - Demonstra a linha de ação de força passando abaixo do CResM e do CResD e a rotação horária que ocorre na maxila e nos dentes, quando é utilizada uma tração alta (adaptação de Teuscher, 1986).

tição (CResD) conforme visualizados na figura lA, o momento e a linha de ação da força.

O centro de resistência (CRes) de um dente unirradicular localiza-se entre o terço médio e o cervical de sua raiz. No primeiro molar superior, o CRes encontra-se próximo da trifurcação das raízes. O CRes de um dente não pode ser modificado pela aplicação de forças externas ${ }^{25,34}$.

Além do CRes do dente, é importante que se verifique a presença do CResD, durante o tratamento ortodôntico corretivo, isto porque, quando, por exemplo, existe um arco maxilar unindo os dentes, estes passam a responder como uma única estrutura $^{40}$. A determinação do CResD depende do número de dentes envolvidos e do tamanho das suas raízes. Por exemplo, casos em que todos os dentes superiores estejam no arco, exceto primeiros pré-molares e segundos molares, o CResD estaria na altura do terço médio da raiz do segundo pré-molar ${ }^{4}$. E, deve-se considerar também o CResM, que responde por essas estruturas ósseas (Fig. 1A). Diferentemente do exposto neste trabalho, Ricketts ${ }^{37}$ afirmou que o CResM se localiza na parte superior da fissura pterigomaxilar.

Enfim, o efeito da utilização do aparelho extrabucal depende da interação de alguns fatores, dentre 
eles destacando-se: os centros de resistência do molar, da dentição (Ortodontia corretiva) e da maxila; a magnitude de força; a linha de ação da força; os tipos de tração; o comprimento e a inclinação do arco externo do AEB; a resistência à movimentação e o estágio de crescimento (Fig. 7). Quando se deseja que a estrutura óssea e a dentária transladem ou que a inclinação dentária seja insignificante, a linha de ação da força deve passar pelos centros de resistência da dentição e da maxila ${ }^{21,25,34}$, como mostra a figura 13 ou entre os centros de resistência da dentição e da maxila ${ }^{40}$, como se observa nas figuras 8,10 e 12 . Se a resultante de força, que é representada pela linha que passa pela extremidade do arco externo até o ponto de ancoragem extrabucal (linha de ação de força), não coincidir com o CRes, cria-se um momento e, conseqüentemente, um centro de rotação (CRot). A mensuração do momento é obtida pela multiplicação da força pela distância perpendicular do CRes à linha de ação da força e, quanto maior essa distância ou a intensidade da força, maior a tendência rotacional das estruturas receptoras dessa força ${ }^{25,34}$.

A figura 15 demonstra como se pode reduzir o momento, por exemplo, com a diminuição da distância entre o CRes do dente e a linha de ação de força. De uma maneira prática, a inversão da posição do tubo onde o arco interno do aparelho extrabucal se insere, de uma posição oclusal para cervical, é uma forma de produzir um momento menor, e portanto, menor tendência de inclinação do molar durante o movimento de distalização. Talvez uma limitação dessa inversão ocorra naqueles casos clínicos com coroas clínicas baixas ou em indivíduos com higiene bucal desfavorável.

Teuscher ${ }^{40}$ descreveu que a melhor ação para os pacientes em crescimento com má oclusão Classe II de Angle é quando a linha de ação de força passa entre os centros de resistência, da maxila (nasomaxilar) e da dentição, conforme se observa nas figuras 8 , 10 e 12. A figura 8 descreve a linha de ação de força passando entre os centros de resistência da maxila (CResM) e da dentição (CResD) e utilizando-se uma tração baixa, enquanto as figuras 10 e 12, mostram, respectivamente, que a mesma ação é possível com o uso da tração horizontal e alta. Na utilização da tração horizontal, os componentes de força intrusivos e extrusivos são praticamente nulos. Nestes casos os momentos produzidos têm sentidos contrários, e portanto tendem a se anular. Esta é a atuação que minimiza o risco de rotações e, conseqüentemente, as interferências na dentição, além de diminuir o risco de rotações mandibulares. A figura 13 demonstra que o mesmo vetor de força pode criar translação, se a linha de ação de força coincidir com os CResM e CResD, sem produzir centro de rotação nem momento, e nesta situação, como a tração é alta, o componente de força intrusivo estará intensificado. Quando se deseja movimento de translação da dentição e, ao mesmo tempo, que tal movimento ocorra praticamente sem extrusão ou intrusão, recomendase a utilização da tração horizontal de maneira que a linha de ação de força coincida com o centro de resistência da dentição (Fig. 11). No entanto, deve ser considerada a rotação horária que ocorrerá na maxila. O problema maior é quando a linha de ação de força não estabelece nenhuma destas relações com os centros de resistência, e passa, por exemplo, abaixo do CResM e do CResD. Assim, os sentidos da rotação da maxila e da dentição são coincidentes causando excessiva rotação maxilar, como pode ser observado nas figuras 9 e 14 para trações baixa e alta respectivamente.

Dessa forma, verifica-se a necessidade de diferentes tipos de tração (baixa, horizontal e alta), de comprimentos do arco externo (curto, médio e longo), bem como diferentes inclinações destes últimos, de modo a proporcionar várias combinações de acordo com a necessidade de cada paciente. A tração alta, pelo fato de ter sua linha de ação de força no sentido superior, tende a intruir os dentes de suporte, e a dificuldade de que esta coincida com o centro de resistência, provoca também alguma rotação. A tração média é aquela que produz menor magnitude de momento (rotação) e tanto o movimento intrusivo quanto o extrusivo são mínimos. Por outro lado, a tração baixa causa extrusão dos dentes de suporte e 
alguma rotação é bastante comum ${ }^{25,34,42}$.

Os efeitos produzidos pela combinação entre os diferentes tipos de tração, comprimentos e inclinações do arco externo do aparelho extrabucal podem ser visualizados nas figuras 4, 5 e 6 , para as trações baixa, média e alta, respectivamente.

A ocorrência ou não dos movimentos extrusivos e intrusivos pode ser determinante para o sucesso do tratamento. A extrusão dos dentes posteriores acentua o padrão vertical do paciente, pois quando a extrusão e/ou crescimento vertical obtido nessa região posterior é maior do que aquele na região condilar, será produzida uma rotação horária da mandíbula ${ }^{4,14,38}$. Essas variações entre o crescimento do côndilo e do complexo nasomaxilar são responsáveis pela rotação da mandíbula e, o valor do ângulo goníaco afeta a quantidade de rotação. A extrusão excessiva dos molares provoca uma rotação horária da mandíbula, dificultando a redução da grandeza cefalométrica $\mathrm{ANB}$, dessa forma dificultando a correção dentária e, principalmente, esquelética da má oclusão Classe II de Angle (Fig. 2). Portanto, no tratamento dessa má oclusão com o aparelho extrabucal, a excessiva rotação horária da mandíbula e a alteração da sua direção de crescimento da mesma são responsáveis pela complexidade de sua correção.

\section{Magnitude de força e tempo de utilização Magnitude de força}

$\mathrm{Na}$ utilização do aparelho extrabucal, vários fatores devem ser observados, como descrito anteriormente. $\mathrm{O}$ conhecimento das magnitudes de força e suas conseqüências devem ser considerados, pois o sucesso dessa intervenção é obtido também em função da magnitude de força aplicada. Basicamente para produzir movimentação ortodôntica, se utiliza forças leves ou ideais e para gerar alterações ortopédicas, utiliza-se forças pesadas.

As forças leves variam de 180 a 350 gramas e as pesadas de 600 a 1000 ou 1500 gramas $^{29}$. Ricketts $^{37}$ alertou que, embora muitos profissionais considerem o AEB um aparelho de efeito puramente dentário, ele se enquadra melhor na categoria de aparelho ortopédico, uma vez que as alterações no complexo nasomaxilar podem ser observadas nos três planos do espaço. E complementou que, para movimentos de natureza ortodôntica, as magnitudes de força variam em torno de 150 a 250 gramas de cada lado, podendo ser diminuídas.

Segundo Lundströn ${ }^{30}$, a reabsorção óssea direta ocorrerá se a magnitude de força empregada for de aproximadamente $100 \mathrm{~g} / \mathrm{cm}^{2}$ de área radicular exposta ao movimento; porém se a magnitude de força girar em torno de $200 \mathrm{~g} / \mathrm{cm}^{2}$, a reabsorção será denominada de indireta ou à distância.

As forças leves têm aproximadamente $20 \mathrm{gm} / \mathrm{cm}^{2}$ da superfície dentária, e por definição, provocam o movimento ortodôntico. Essas forças geram pressão de um lado do ligamento periodontal e tensão do outro, produzindo, respectivamente, reabsorção e aposição óssea que por sua vez provocarão a movimentação fisiológica do dente 6 . Quando uma força leve e prolongada é aplicada sobre o dente ocorre a diminuição do fluxo sangüíneo logo após o fluido ser eliminado do espaço periodontal e o dente se move dentro do alvéolo em poucos segundos. Em poucas horas a atividade química estará modificada no ligamento periodontal e após 4 horas iniciam-se diferenciações celulares. Como conseqüência produzirão o movimento dentário em aproximadamente 2 dias com a remodelação óssea da parede alveolar por osteoclastos e osteoblastos (reabsorção óssea direta). Por este motivo, os aparelhos removíveis não terão resultado nenhum se utilizados por menos de 4 horas seguidas ${ }^{35}$.

As forças pesadas produzem efeito ortopédico no complexo nasomaxilar, de acordo com as teorias clássicas. O que ocorre é uma pressão do dente contra a lâmina cortical do alvéolo no lado oposto à aplicação da força, causando isquemias que induzem à reabsorção óssea minante ${ }^{8}$. Quanto mais intensa for a pressão aplicada, maior será a redução no fluxo sanguíneo nas áreas comprimidas do ligamento periodontal, até o ponto em que os vasos se tornam totalmente colapsados e sem fluxo sangüíneo. E, se esta força pesada se mantém 
presente por algumas horas, ocorre morte celular, se persistir por 3 a 5 dias, a reabsorção minante se inicia. E, no período de 7 a 14 dias, a reabsorção minante remove a lâmina dura adjacente à área comprimida no ligamento periodontal, ocorrendo, assim, o movimento dentário ${ }^{35}$.

Baumrind et al. ${ }^{8}$, após investigarem os movimentos ocorridos após tratamento com aparelho extrabucal com tração baixa e alta, discordaram sobre forças leves causarem simplesmente movimento ortodôntico e pesadas, ortopédico. Verificaram que os dois tipos de movimento ocorrem. Com a tração baixa, o efeito ortopédico é maior que o ortodôntico, mas os dois estão presentes. $\mathrm{Na}$ tração alta, a distalização dos molares foi muito maior do que o efeito ortopédico, nas suturas do crânio.

Embora ocorra morte celular quando se utiliza força pesada (quando se deseja efeito ortopédico), o ritmo da força aplicada é intermitente, ou seja, os níveis de força declinam abruptamente para zero, de maneira intermitente, quando o aparelho é removido pelo paciente. $\mathrm{O}$ que deve ser considerado altamente desfavorável é a utilização de força pesada de maneira contínua, pois ocorreriam seguidas reabsorções minantes sem que houvesse tempo necessário para a reorganização dos tecidos adjacentes.

Para $\mathrm{Graber}^{20}$, a força ótima varia muito de um indivíduo para o outro. No entanto, afirmou que uma força superior a 400 gramas é suficiente para deter o movimento mesial dos dentes durante o crescimento da maxila para frente.

A força ótima indicada por Ghafari et al. ${ }^{19}$ é de 435 a 497 gramas por lado. Wheeler et al. ${ }^{45}$ recomendaram 497 gramas de força para cada lado. Já Ricketts ${ }^{37}$ recomendou para alterações ortopédicas, em média, 500 gramas de cada lado durante a dentição mista e 750 gramas durante o final da dentição mista e início da permanente. A força tolerada pelos pacientes quando se utiliza a tração média é de 1.015 a 1.171 gramas, tanto para homens e mulheres ${ }^{33}$.

\section{Tempo de utilização}

O número de horas de utilização é essencial para o sucesso da intervenção com AEB no tratamento da má oclusão Classe II de Angle.

O tempo de utilização ideal do aparelho extrabucal é de 14 horas por dia, sendo removido durante a alimentação, para escovar os dentes e durante a prática de esportes ${ }^{19,26,45}$. A utilização de 12 a 14 horas por dia também pode ser considerada adequa$\mathrm{da}^{11,29,46}$. Para Wieslander e Buck ${ }^{46}$, esse limite mínimo deve ser aumentado de acordo com a gravidade do problema a ser tratado. Por outro lado, Ricketts ${ }^{37}$ advertiu que o tempo de uso do AEB com tração cervical não deve exceder 15 horas por dia, pois sobrecarrega a musculatura e gira a mandíbula no sentido horário, modificando a resposta do crescimento.

\section{Efeitos dento-esqueléticos da utilização do aparelho extrabucal}

Ao estudarem os efeitos da força ortodôntica no complexo nasomaxilar, Proffit e Fields ${ }^{35}$ afirmaram que é possível restringir o seu deslocamento ântero-inferior empregando as forças que se opusessem às forças naturais que separam as suturas, minimizando essa separação. Segundo os autores, uma força total de 500 gramas provavelmente é o mínimo

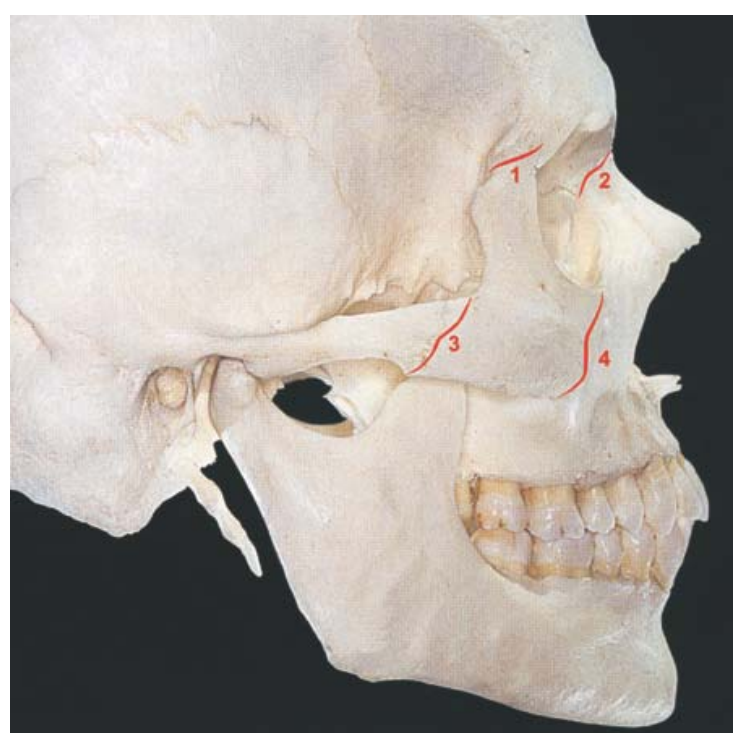

FIGURA 16 - Suturas (visíveis externamente em um crânio seco) que unem a maxila ao crânio e que estão diretamente relacionadas com a utilização do AEB. 
para impedir o deslocamento para a frente e para baixo do complexo nasomaxilar. As principais suturas que unem o complexo nasomaxilar ao crânio são zigomaticomaxilar, pterigomaxilar, frontomaxilar/nasal e frontozigomática (Fig. 16).

Para Enlow $^{16}$ crescimento que ocorre nas suturas é passivo e, portanto, não induz ao deslocamento. Segundo o autor, as suturas não fornecem estímulos primários que conduzam ao deslocamento e à aposição do osso, são os tecidos vizinhos que, pelo seu próprio crescimento, provocam a separação das suturas e, por sua vez, estimulam a aposição óssea sobre suas superfícies.

O aparelho extrabucal com tração baixa é capaz de diminuir a convexidade facial, como demonstrado por Blueher ${ }^{11}$. Esta tendência foi observada em 33 das 34 crianças participantes do estudo por meio da utilização da grandeza cefalométrica NAPo (násio - ponto $\mathrm{A}$ - pório).

A atuação do aparelho extrabucal sobre a estrutura maxilar, não apenas restringindo o crescimento anterior, mas também alterando sua posição para distal, foi verificada por Baumrind et al. ${ }^{6}$

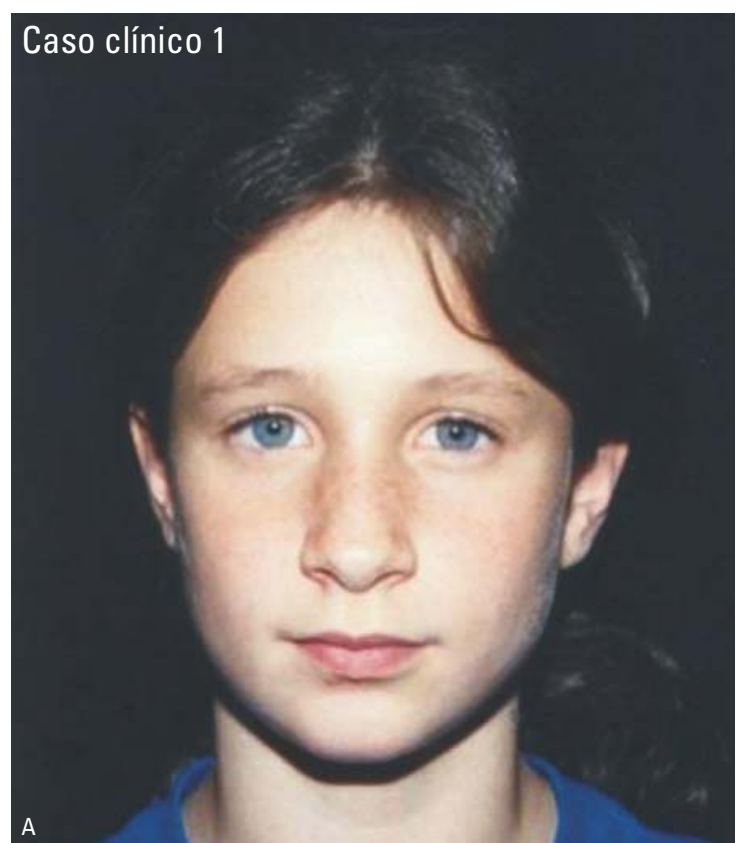

FIGURA 17 - A) Vista frontal extrabucal inicial. B) Vista lateral extrabucal inicial.
Da amostra estudada pelos autores, 37\% apresentaram alguma distalização, no entanto, em apenas $15 \%$ dos casos o deslocamento foi superior a $1 \mathrm{~mm}$. Kopecky e Fishman ${ }^{28}$ observaram a restrição da protrusão maxilar produzida pelo aparelho extrabucal, essa mudança na base esquelética foi avaliada pelo controle do ponto A. Ghafari et al. ${ }^{19}$ verificaram que as forças sobre a maxila causaram redução do SNA, e que isso ocorreu devido à mudança de posição do ponto $\mathrm{N}$, provocada pela restrição do crescimento anterior da maxila. A mudança da posição do complexo nasomaxilar em relação à base craniana anterior tornou-se visível pela redução do prognatismo maxilar $^{31}$. A restrição da maxila é mais facilmente conseguida em meninas do que em meninos, pelo fato de elas terem um menor componente de crescimento anterior do que os meninos ${ }^{11}$.

Estudando as alterações esqueléticas produzidas pela utilização do AEB associado ao tratamento corretivo na resolução da má oclusão Classe II/1, Gandini et al. ${ }^{18}$ concluíram que o AEB não influenciou de maneira significante o crescimento horizontal da maxila, restringindo o seu deslocamento

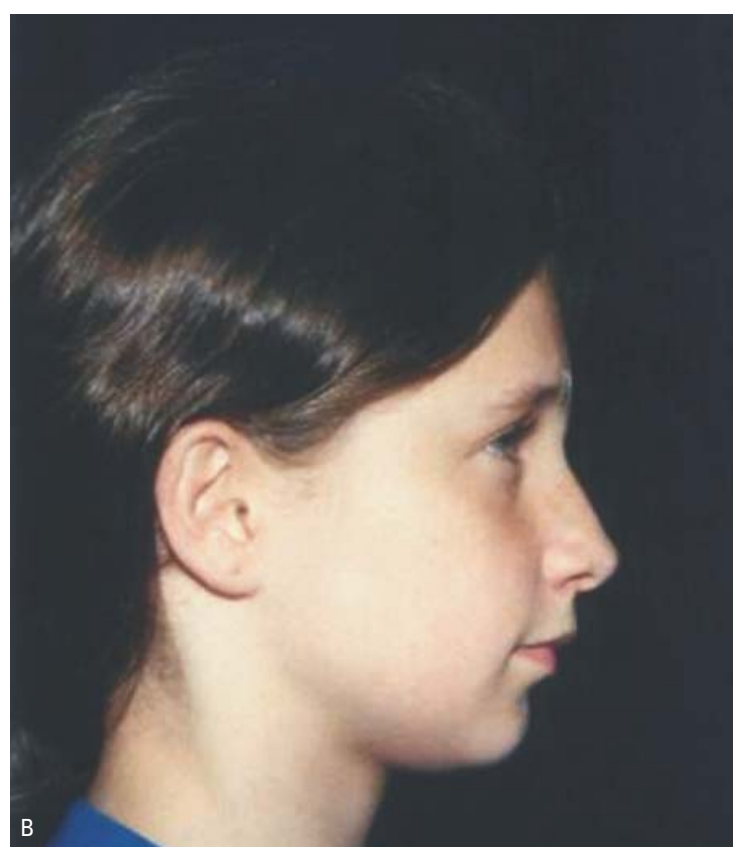



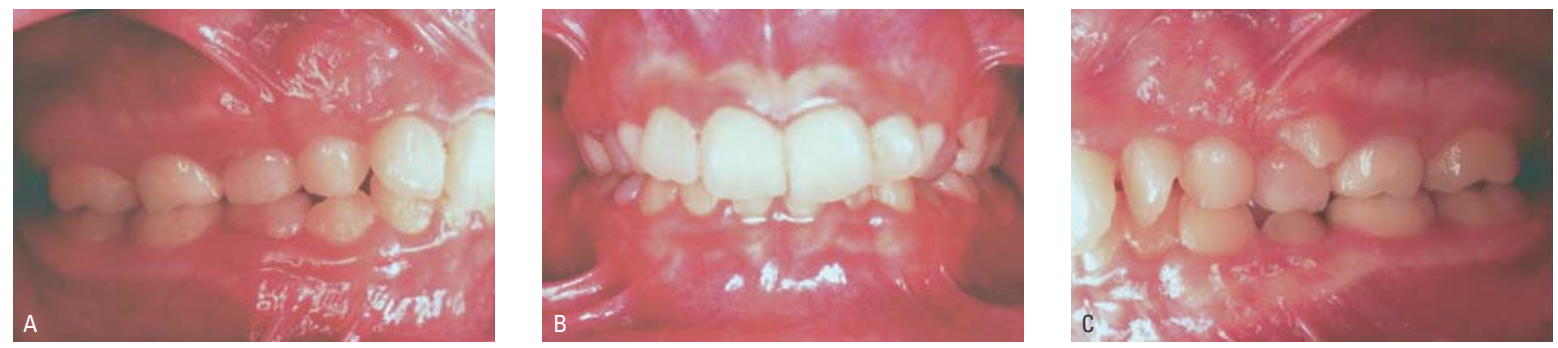

FIGURA 18 - A) Vista lateral direita intrabucal inicial. B) Vista frontal intrabucal inicial. C) Vista lateral esquerda intrabucal inicial.
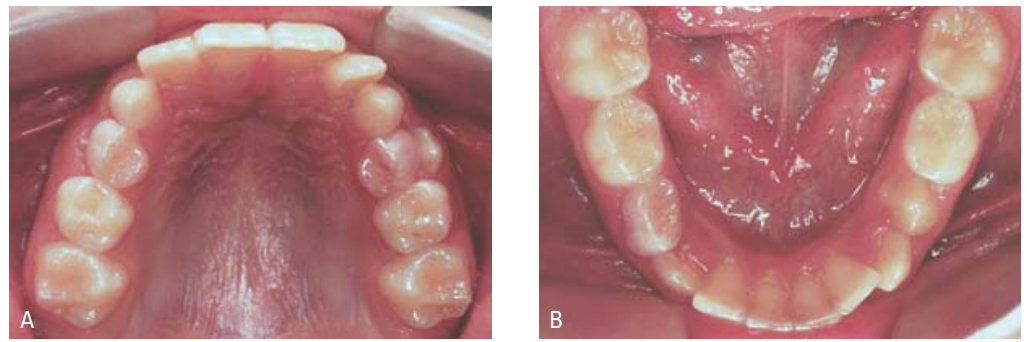

FIGURA 19 - A) Vista oclusal superior intrabucal inicial. B) Vista oclusal inferior intrabucal inicial.

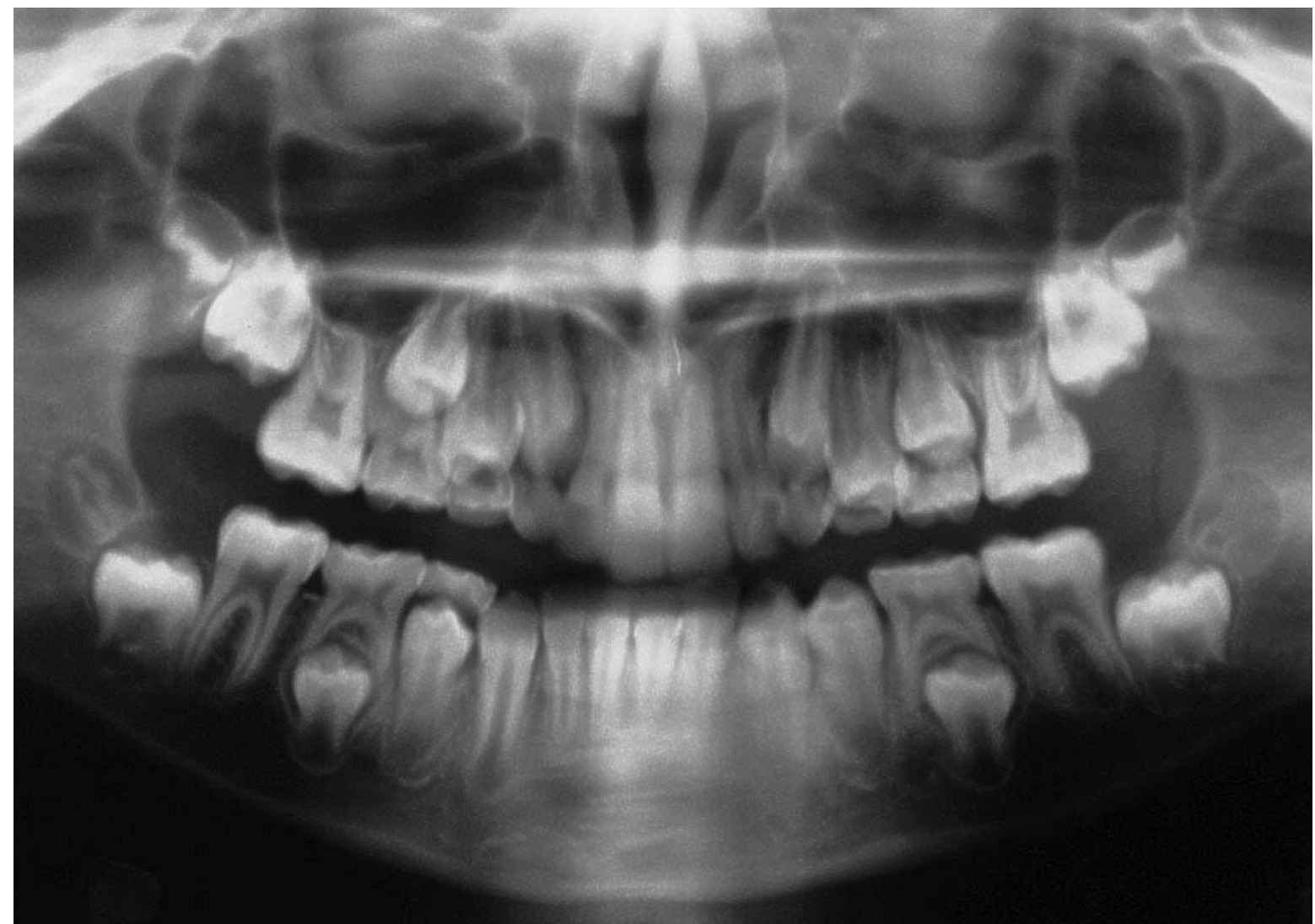

FIGURA 20 - Radiografia panorâmica inicial. 

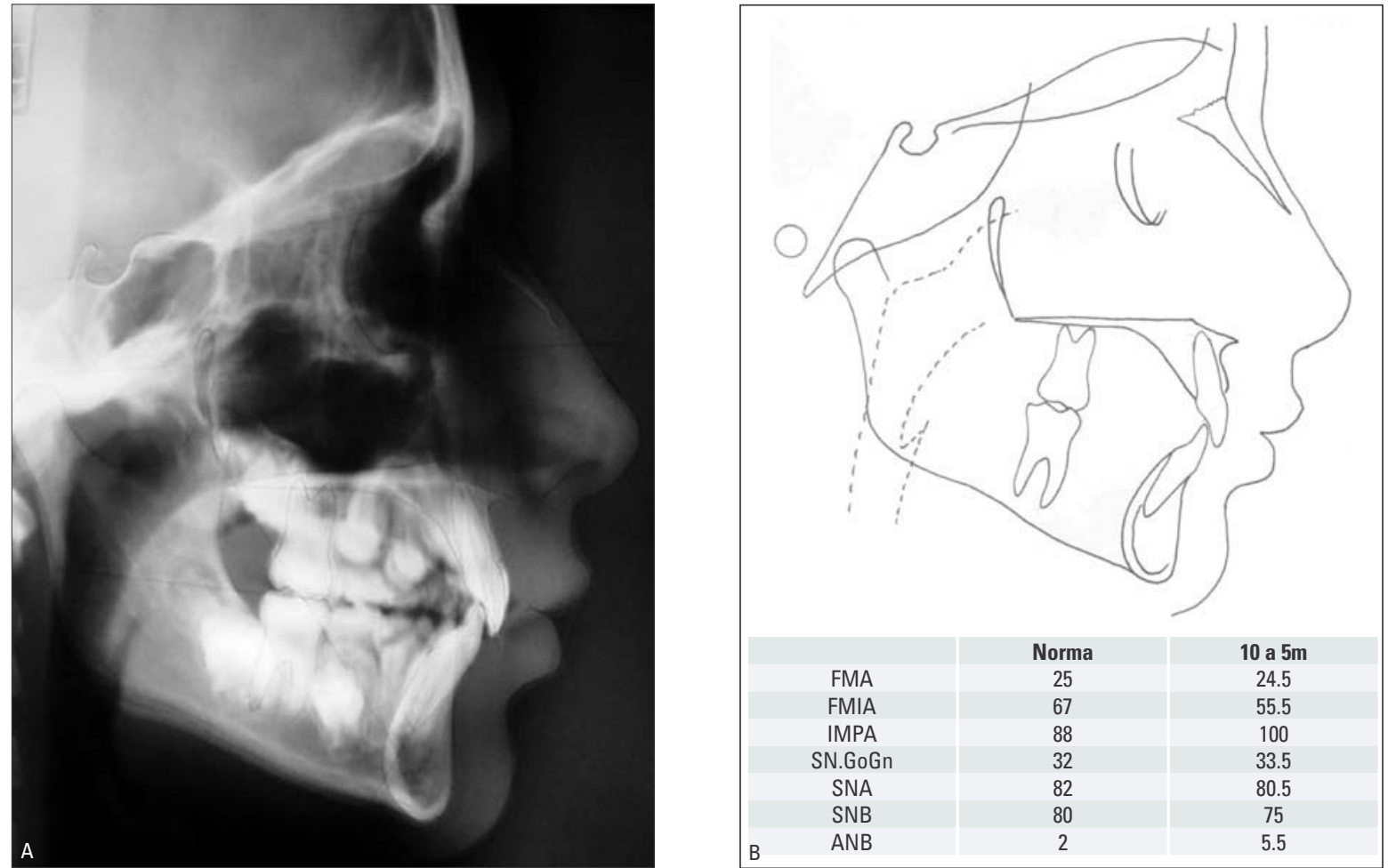

FIGURA 21 - A) Telerradiografia em norma lateral. B) Cefalograma inicial e grandezas cefalométricas iniciais.

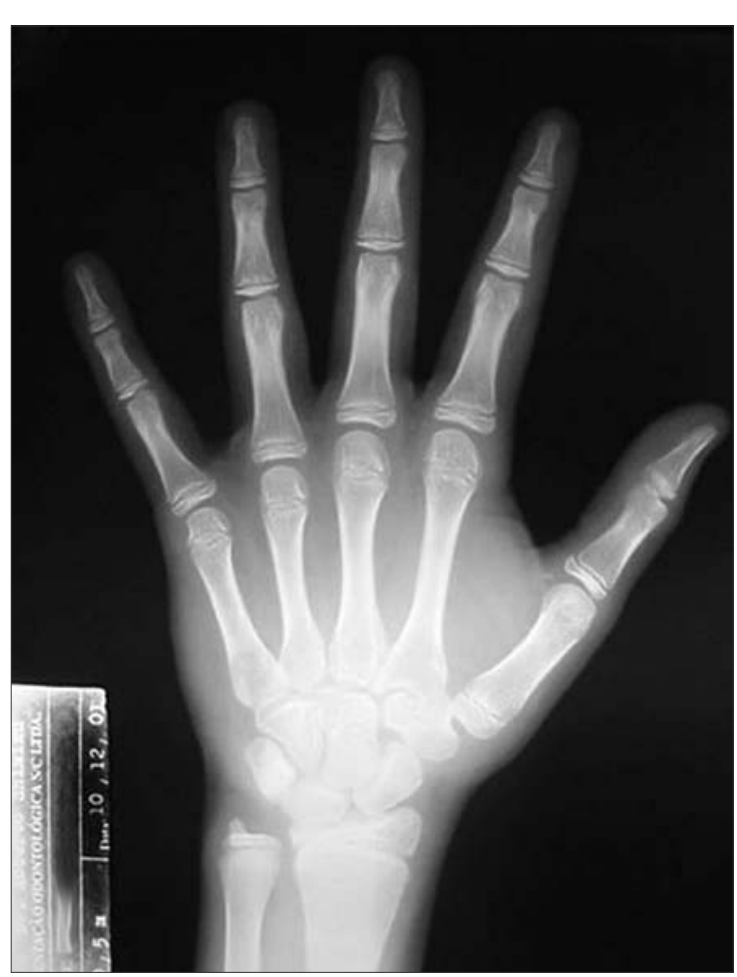

FIGURA 22 - Rx de mão e punho para determinação da idade esquelética. ântero-posterior; não influenciou o crescimento vertical da maxila; não influenciou de forma significativa o crescimento da mandíbula no sentido vertical ou ântero-posterior e reduziu a discrepância ântero-posterior das bases ósseas, mas não foi capaz de influenciá-las na dimensão vertical.

O aparelho extrabucal apresentou-se eficaz na distalização dos molares superiores $2,6,19,28,31,45,46$. Baumrind et $a 1 .{ }^{6}$ observaram que 109 pacientes de uma amostra de 198 pacientes mostraram movimento distal dos molares superiores, no entanto, com um movimento de inclinação da coroa, o que tornava aquele movimento altamente recidivante e, portanto, não tão eficiente. De acordo com Weislander e Buck ${ }^{46}$ o movimento distal dos molares ocorre em conseqüência da resposta dentoalveolar às forças e de mudanças na posição da maxila. Mel$\operatorname{sen}^{31}$ desenvolveu um estudo utilizando implantes metálicos no interior da estruturas ósseas para observar as alterações no crescimento na maxila e na mandíbula após tratamento com aparelho extrabu- 

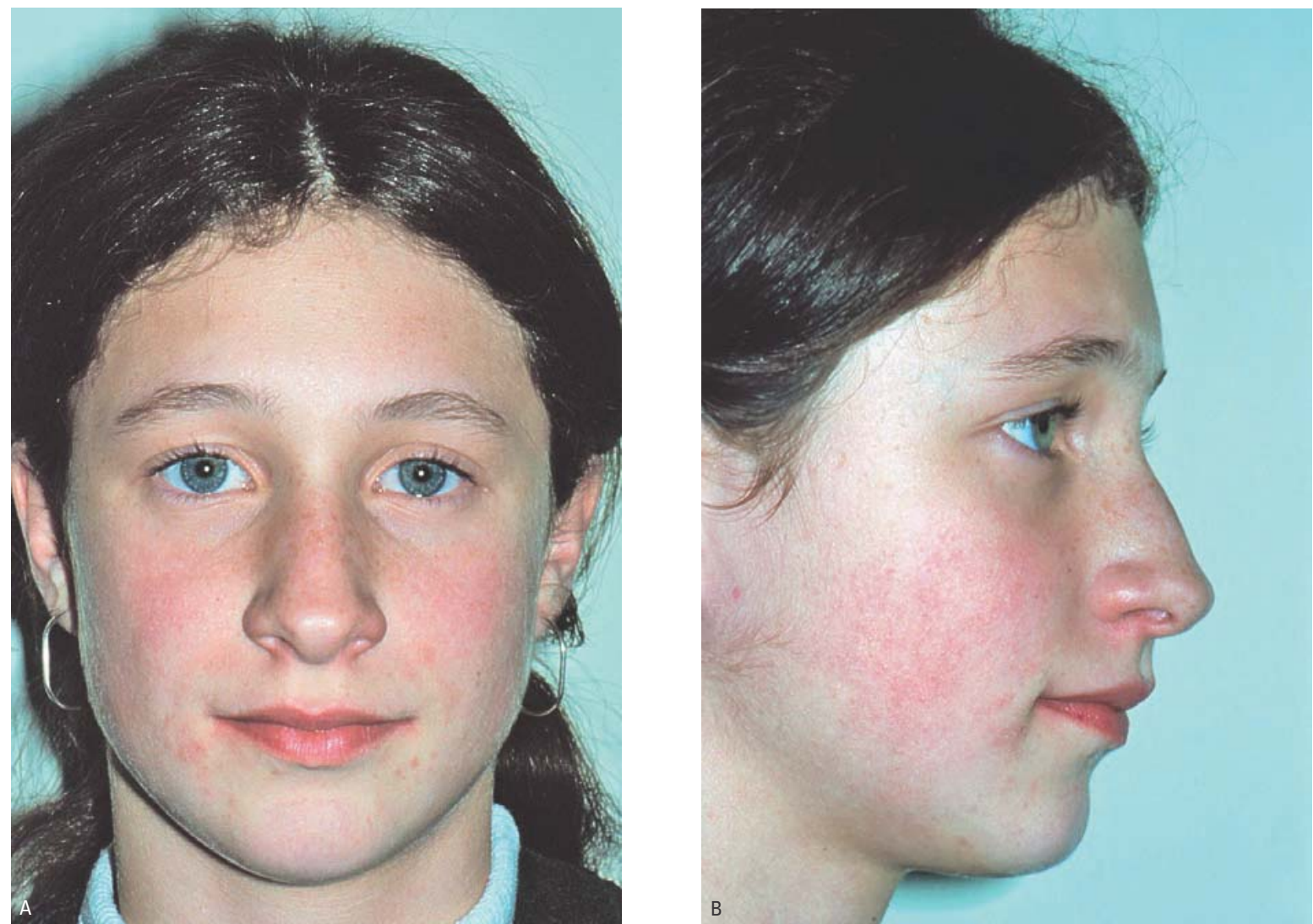

FIGURA 23 - A) Vista frontal extrabucal. B) Vista lateral extrabucal. Após utilização do AEB
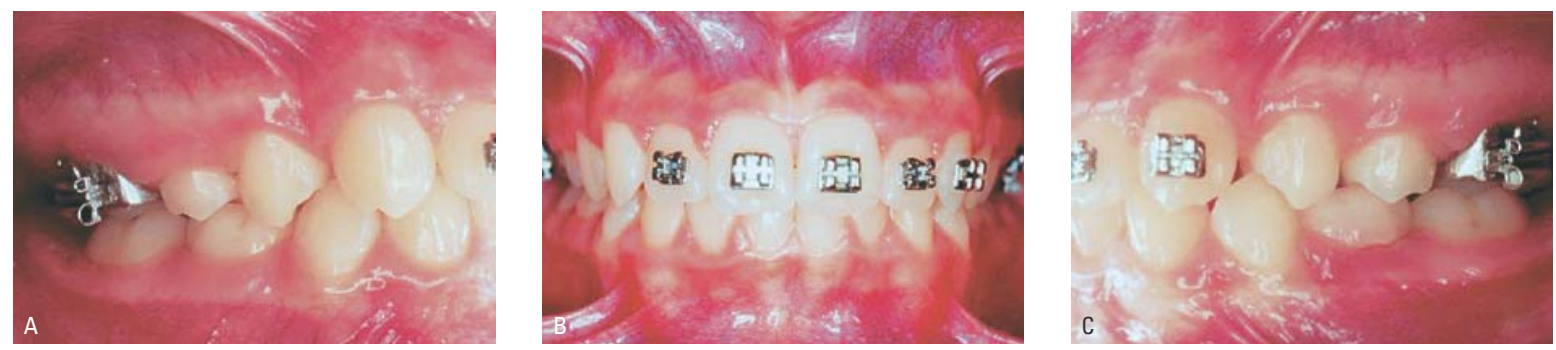

FIGURA 24 - A) Vista lateral direita intrabucal. B) Vista frontal intrabucal. C) Vista lateral esquerda intrabucal. Após utilização do AEB.
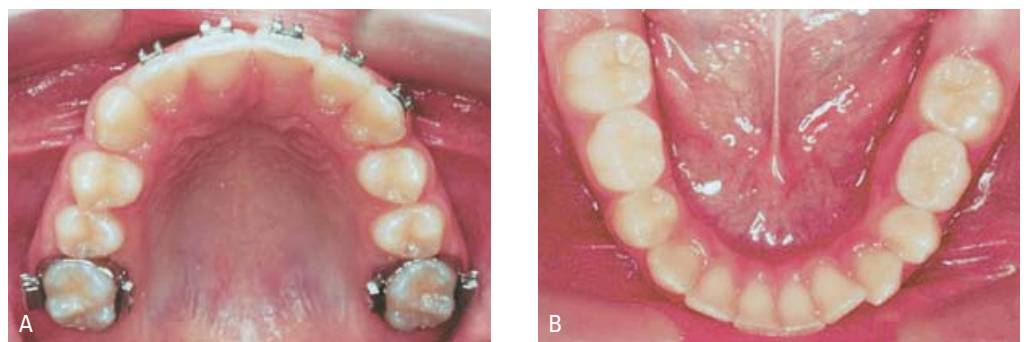

FIGURA 25 - A) Vista oclusal superior intrabucal. B) Vista oclusal inferior intrabucal. Após utilização do AEB. 

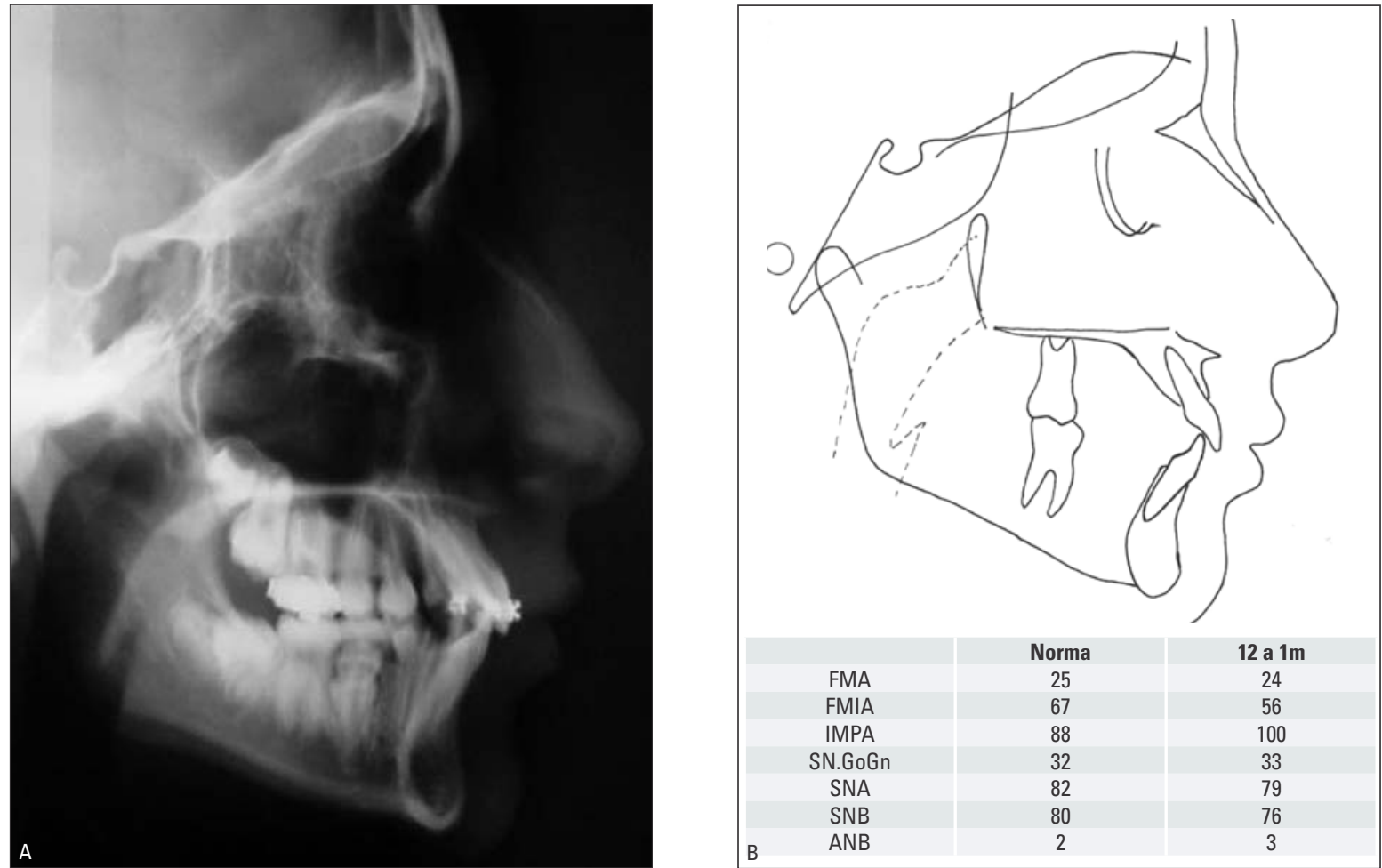

FIGURA 26 - A) Telerradiografia em norma lateral. B) Cefalograma e grandezas cefalométricas. Após utilização do AEB.

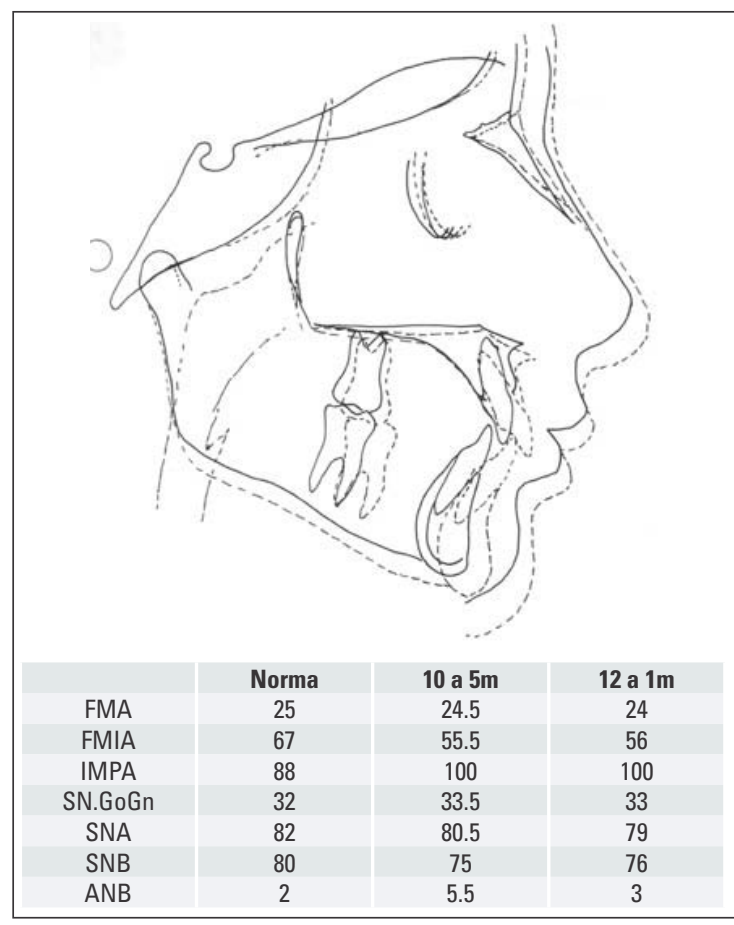

FIGURA 27 - Sobreposição total. Quadro comparativo das grandezas cefalométricas inicias e após utilização do AEB. cal e constatou que ocorreu o movimento distal dos molares. Ashmore et al. ${ }^{2}$ analisaram o movimento tridimensional do molar durante o tratamento com aparelho extrabucal e obtiveram a média de 2,2 $\mathrm{mm}$ de movimento distal. Por outro lado, a ocorrência do movimento distal dos molares superiores não pôde ser confirmada pelos estudos realizados por O'Reilly, Nanda e Close ${ }^{33}$.

Uma observação interessante é a ocorrência do aumento de espaços entre os dentes ântero-superiores denotando a eficácia do aparelho extrabucal em casos com apinhamento anterior ${ }^{19}$. Para Wheeler et $\mathrm{al} .{ }^{45}$, além de o aparelho extrabucal causar o deslocamento distal dos molares superiores, ocorre também o aumento da distância intercaninos e espaçamento entre os dentes anteriores.

Em relação à influência do aparelho extrabucal no crescimento da mandíbula, a literatura apresenta algumas contradições. Para Baumrind et al. ${ }^{7}$, a média de crescimento do corpo mandibular (gônio - mento) não é maior quando se utiliza 

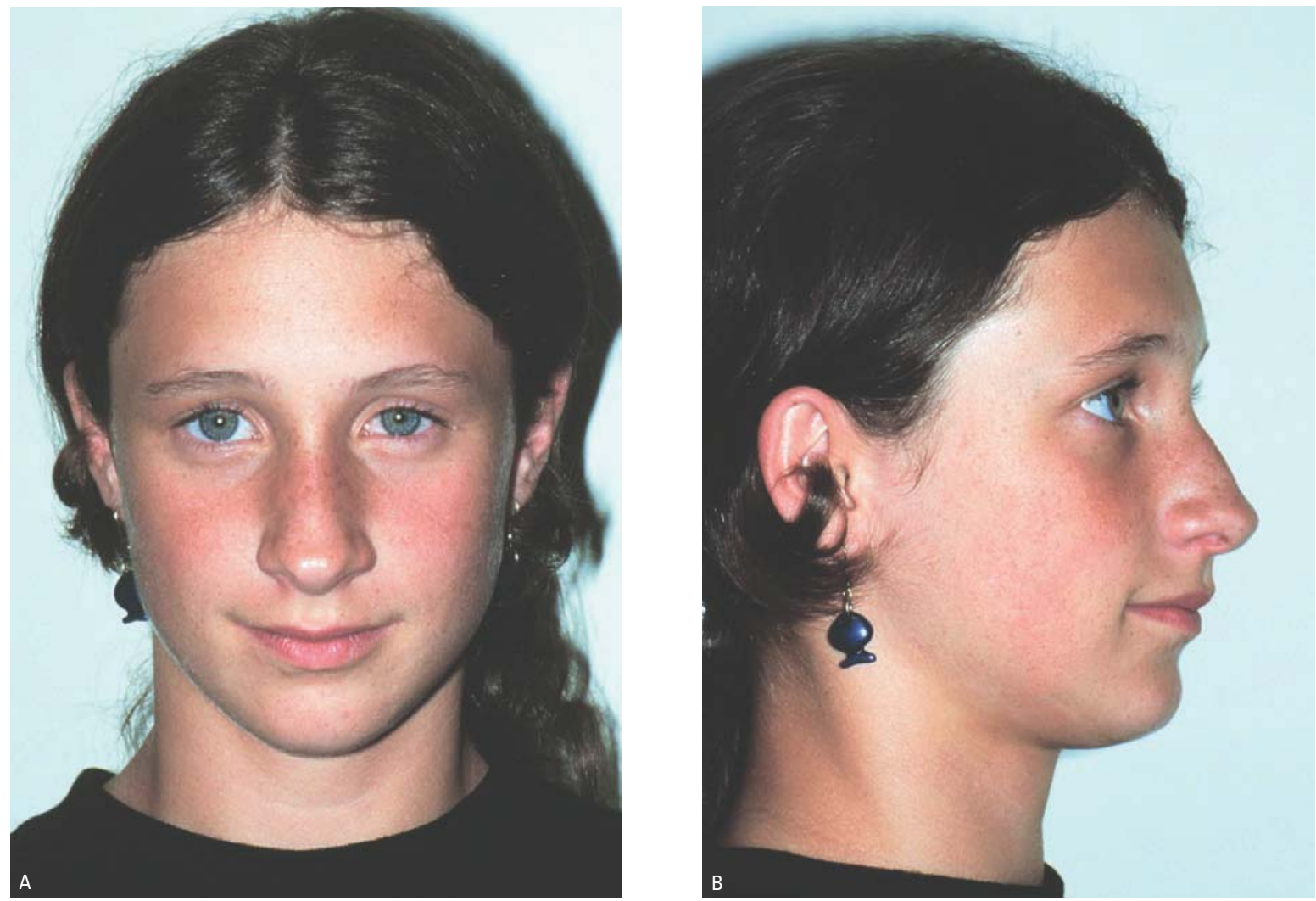

FIGURA 28 - A) Vista frontal extrabucal final. B) Vista lateral extrabucal final. Após remoção dos braquetes dos incisivos superiores e do dente 23.
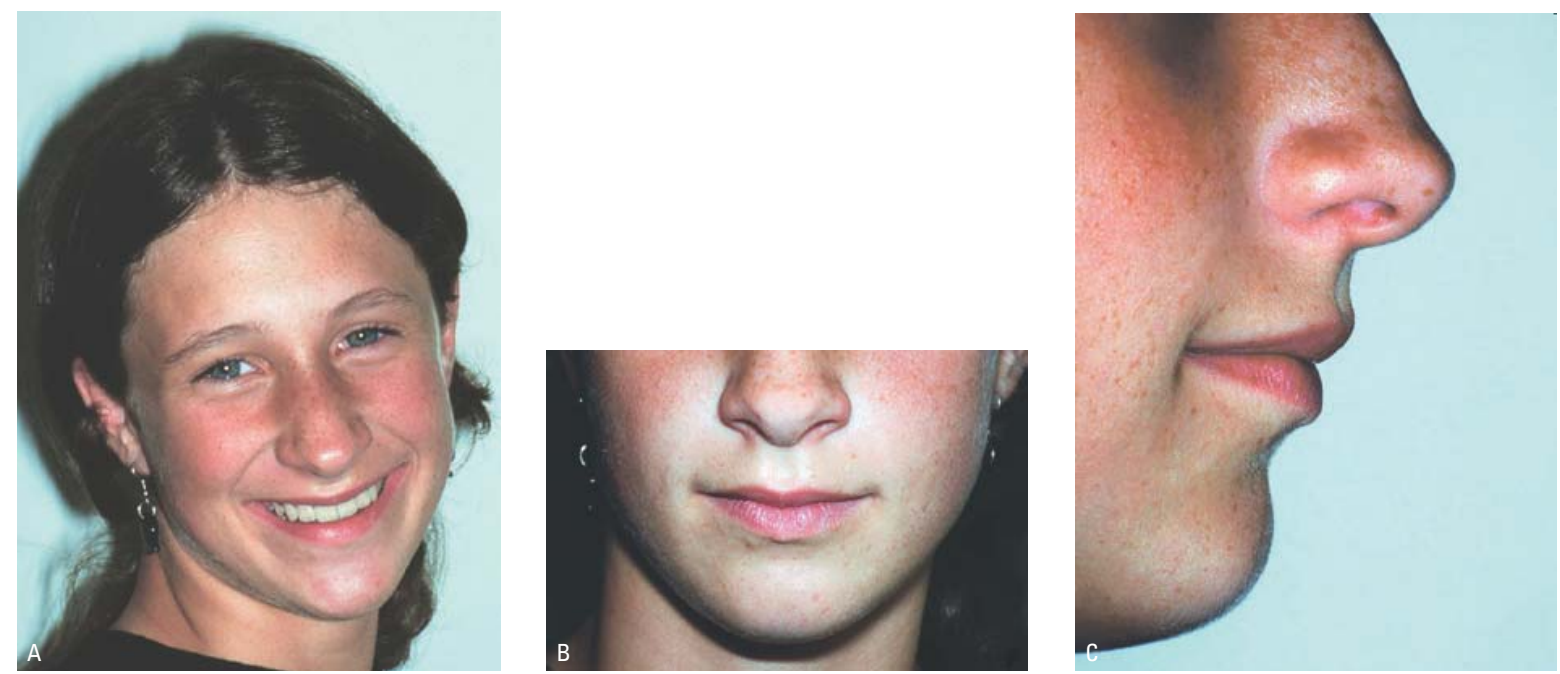

FIGURA 29 - A) Vista sorrindo extrabucal final. B) Vista frontal aproximada extrabucal final. C) Vista lateral aproximada extrabucal final. Após remoção dos braquetes dos incisivos superiores e do dente 23. 

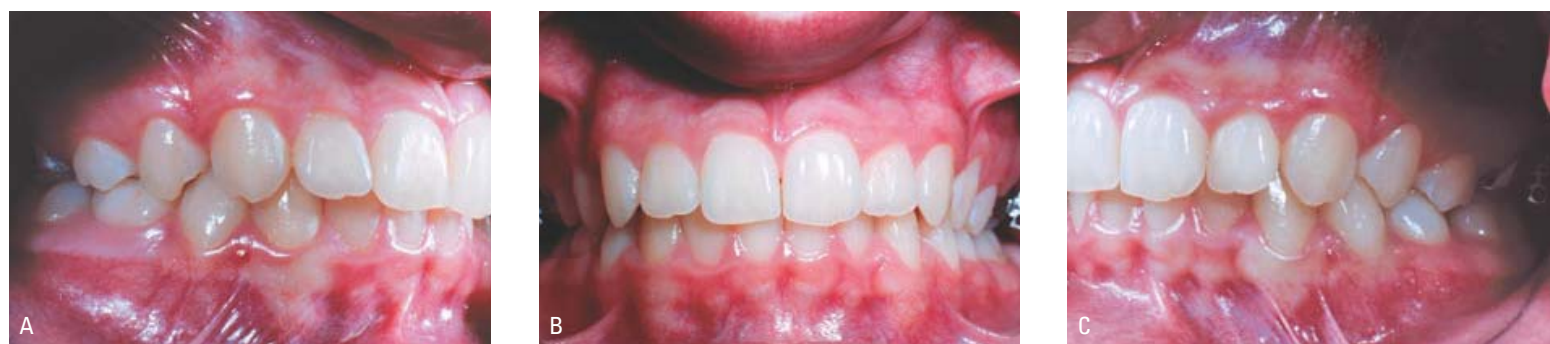

FIGURA 30 - A) Vista lateral direita intrabucal final. B) Vista frontal intrabucal final. C) Vista lateral esquerda intrabucal final. Após remoção dos braquetes dos incisivos superiores e do dente 23.

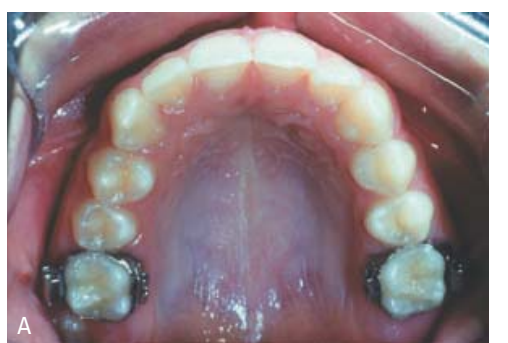

FIGURA 31 - A) Vista oclusal superior intrabucal final. B) Vista oclusal inferior intrabucal final. Após remoção dos braquetes dos incisivos superiores e do dente 23 .

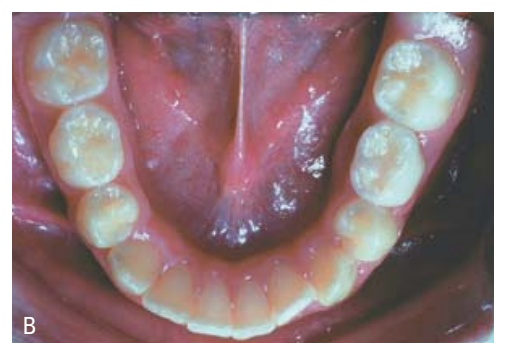

má oclusão Classe II, 1 de Angle, com maxila bem posicionada e mandíbula retruída em relação a base do crânio, discrepância esquelética maxilo-mandibular, dentição mista, overjet de 3,5 mm e overbite de $60 \%$, irrupção ectópica do dente 24 , apinhamento ântero-superior, linhas médias superior desviada 2,0 $\mathrm{mm}$ e a inferior $0,5 \mathrm{~mm}$ para esquerda (Fig. 17-22).

O tratamento preconizado, apesar da análise cefalométrica acusar retrusão mandibular, foi por meio da utilização do AEB com tração horizontal (KHG). O objetivo do tratamento foi restabelecer a relação molar em Classe I, diminuindo simultaneamente a discrepância esquelética pela restrição do crescimento anterior da maxila e permitindo o crescimento normal da mandibula, sem, no entanto, promover a rotação horária da mandíbula. Para essa fase do tratamento foi realizado apenas o tratamento interceptativo com AEB e, colados somente os dentes 11, 12, 21, 22 e 23 para melhorar o alinhamento dos incisivos laterais e do dente 23 que irrompeu inclinado para vestibular (Fig. 23-27). Após essa fase, se aguardará a evolução da biogênese para posterior tratamento corretivo (Fig. 28-31). 


\section{Aparelho extrabucal assimétrico}

Muitas vezes é necessário que a força distal gerada pelo aparelho extrabucal seja maior de um lado do que a do outro, seja por uma subdivisão ou posição assimétrica ântero-posterior dos molares. As assimetrias nas relações molares direito/ esquerdo podem ser corrigidas pelo uso de arco transpalatal, o qual corrige a inclinação axial e/ou a rotação assimétrica do molar. Entretanto, se a má oclusão é uma subdivisão, ou seja, de um lado a relação molar é de Classe I e do outro de Classe II, sem assimetrias tanto na inclinação axial quanto na rotação, então a melhor indicação seria o uso de um aparelho extrabucal assimétrico ${ }^{23,34}$.

As variações e os tipos de aparelhos são muitos. Hershey, Houghton e Burstone ${ }^{23}$ realizaram um estudo comparativo de cinco tipos de aparelhos extrabucais. Os designs dos aparelhos analisados foram: 1) simétrico bilateralmente, 2) arco externo mais longo e expandido de um lado, 3) solda fixa entre os arcos externo e interno descentralizada, 4) arco externo unido ao interno por uma articulação swivel e 5) mola aberta na extremidade do arco interno de um aparelho extrabucal simétrico. Todas as modificações foram realizadas no lado em que se desejava gerar maior força distal. Dentre os objetivos dos autores estavam: verificar quais deles gerariam força distal unilateral, como e qual a previsibilidade das forças laterais geradas com estes aparelhos e qual seria o design de aparelho extrabucal mais efetivo e prático para o uso clínico. Os resultados demonstraram que os aparelhos com arco externo mais longo e expandido de um lado e o com articulação swivel foram os mais efetivos na distribuição de força distal assimétrica, e que estes aparelhos também produziam força lateral nas extremidades do arco interno. A quantificação da força lateral em cada design de aparelho não pôde ser obtida, mas verificaram que sua magnitude aumenta quanto mais efetivo for o aparelho extrabucal assimétrico no sentido distal.

A indicação do aparelho extrabucal assimétrico com um arco externo mais longo também é feita por outros autores, como Oosthuizen, Dijkman e
Evans $^{34}$ e Langlade ${ }^{29}$.

Oosthuizen, Dijkman e Evans ${ }^{34}$ fizeram considerações interessantes quanto ao mecanismo de distribuição de força assimétrica por meio de expansão de um lado do arco externo sem que seu comprimento seja alterado, como sugerido por Terra $^{39}$. Os autores demonstraram matematicamente que esta tentativa de aumentar o componente de força distal é ineficiente, pois a angulação entre a linha de ação de força e a linha média sagital se mantém praticamente inalterada, podendo inclusive produzir efeito contrário. Além disto, o componente de força lateral é aumentado nestas situações, sem que a posição ântero-posterior do molar seja favorecida. Portanto, a expansão de um dos lados do arco externo, sem que o comprimento deste seja aumentado não seria uma escolha adequada para se produzir maior força distal.

Assim, Langlade ${ }^{29}$ recomendou aumentar o comprimento do arco externo no lado que se deseja maior distalização e advertiu que, nesse lado do arco externo maior também será gerado um momento maior. Afirmou ainda que, quando comparados, dois tipos de arcos faciais, o primeiro com o ponto de solda entre o arco interno e o externo centralizado e o segundo, com o ponto de solda deslocado lateralmente, geram as mesmas magnitudes de força e os momentos se anulam.

\section{Barra Palatina}

Em diversas situações clínicas, a barra palatina (BP) tem sido empregada devido à sua fácil confecção, ao controle tridimensional e à variedade de opções mecânicas ${ }^{36}$.

Especificamente na correção da má oclusão Classe II de Angle, a BP é utilizada para distalização dos molares naqueles casos clínicos tratados sem extrações em que os dentes são distalizados unilateral e alternadamente ${ }^{13}$. Este mecanismo gera necessariamente um momento indesejável que produziria rotação no molar utilizado para ancoragem. Para minimizar a rotação do molar, Melsen et al. ${ }^{32}$ propuseam a utilização da BP estaticamente 
ativada, que apresenta encaixe em somente um dos lados (de ancoragem) e no lado a ser distalizado. A BP deve ser amarrada por vestibular, proporcionando assim um movimento distal sem rotação ${ }^{36}$.

A BP poderá ser construída com fio beta-titânio (TMA) .032" x .032" (Fig. 55) ou com aço inoxidável $0,7 \mathrm{~mm}$ ou $0,8 \mathrm{~mm}$ (Fig. 56). A ativação pode ser visualizada nas figuras $55 \mathrm{~A}, \mathrm{~B}$ e $56 \mathrm{~A}$.

A eficácia do tratamento da má oclusão Classe II com a utilização da BP pode ser observada tanto para aquelas situações em que ambos os molares estão em Classe II, quanto para a má oclusão Classe II sub-divisão. Na primeira situação, as ativações são realizadas alternadamente podendo utilizar, simultaneamente, o aparelho extrabucal (AEB) com o intuito de contrapor a tendência de mesialização do molar utilizado para ancoragem e otimizar a distalização do lado oposto, além de controlar o movimento rotacional, principalmente, no lado de ancoragem. O sistema de forças da BP ativa associada com o AEB pode ser visualizado na figura 38. Após a distalização necessária, inverte-se o mecanismo para o lado oposto. Já para a má oclusão Classe II subdivisão, essa mesma mecânica (BP e AEB) é aplicada somente para o lado da subdivisão.

Importante enfatizar que para o melhor controle e eficácia da mecânica utilizando a BP durante o tratamento ortodôntico corretivo, o molar a ser distalizado não deve estar inserido no arco (que inclui desde o molar do lado oposto até o segundo pré-molar). Este arco auxiliará na ancoragem do lado que não precisa ser distalizado e contribuirá também para minimizar a rotação do molar de ancoragem (Fig. 48).

E para que o molar distalize sem rotacionar se realiza uma ativação anti-rotacional de 50\% em relação ao lado oposto preconizada por Panhóca e Lima (apud RAMOS et al.) ${ }^{36}$. Ainda em relação às ativações, recomenda-se expandir a BP à medida que o dente for distalizando, uma vez que normalmente o arco é divergente para posterior e poderia ocasionar o cruzamento desse dente.

O caso clínico 2 de uma adolescente com má oclusão Classe II, 2 sub-divisão direita, ilustra a utilização do AEB (Kloehn) associado à BP (Fig. 32 a 43). A adolescente E.P., gênero feminino, 10 anos e 8 meses, braquifacial, apresentava má oclusão Classe II, 2 sub-divisão direita de Angle, com protrusão maxilar e mandíbula bem posicionada em relação à base do crânio, dentição mista, dentes 22 e 23 impactados, dilaceração radicular do dente 22 , respiração predominantemente bucal, perfil côncavo, linha média superior desviada 3,0 $\mathrm{mm}$ para esquerda e inferior coincidente com plano sagital mediano, overjet de 3,0 mm e overbite de 100\%.

Para tanto, utilizou-se o AEB associado com a BP ativa para o lado direito objetivando maior distalização do molar do lado da sub-divisão, que neste caso é o da direita. Em seu sistema de forças, a BP desenvolve uma força distal sobre o dente 16, entretanto, promove também uma força mesial sobre o dente 26, além de uma tendência rotacional neste último. A utilização do $\mathrm{AEB}$ associado à $\mathrm{BP}$ é justamente para minimizar o efeito de rotação e de mesialização do dente 26 que é utilizado como ancoragem, e, ainda, potencializar a distalização do dente 16 (Fig. 38). Neste caso clínico, para essa fase do tratamento, foi realizado apenas o restabelecimento da relação molar em Classe I do lado da subdivisão, verificando-se também uma sobrecorreção do lado esquerdo e uma melhora significativa da relação dos caninos. Uma vez alcançado o objetivo, a próxima fase será o tratamento ortodôntico corretivo para o restabelecimento da oclusão normal.

E, finalmente, o caso clínico 3 da menor N.F., 12 anos e 10 meses, gênero feminino, com má oclusão Classe II, divisão 1, mesofacial, com maxila relativamente bem posicionada e a mandíbula retruída em relação à base do crânio, bom selamento labial, dentição mista, linhas médias superior e inferior coincidentes com plano sagital mediano, overjet de 3,0 mm e overbite de 20\%, Este caso clínico ilustra a utilização da BP para controlar a distalização diferenciada dos primeiros molares direito e esquerdo, que se encontram em posições diferentes no sentido ântero-posterior. Essas posições se devem provavel- 

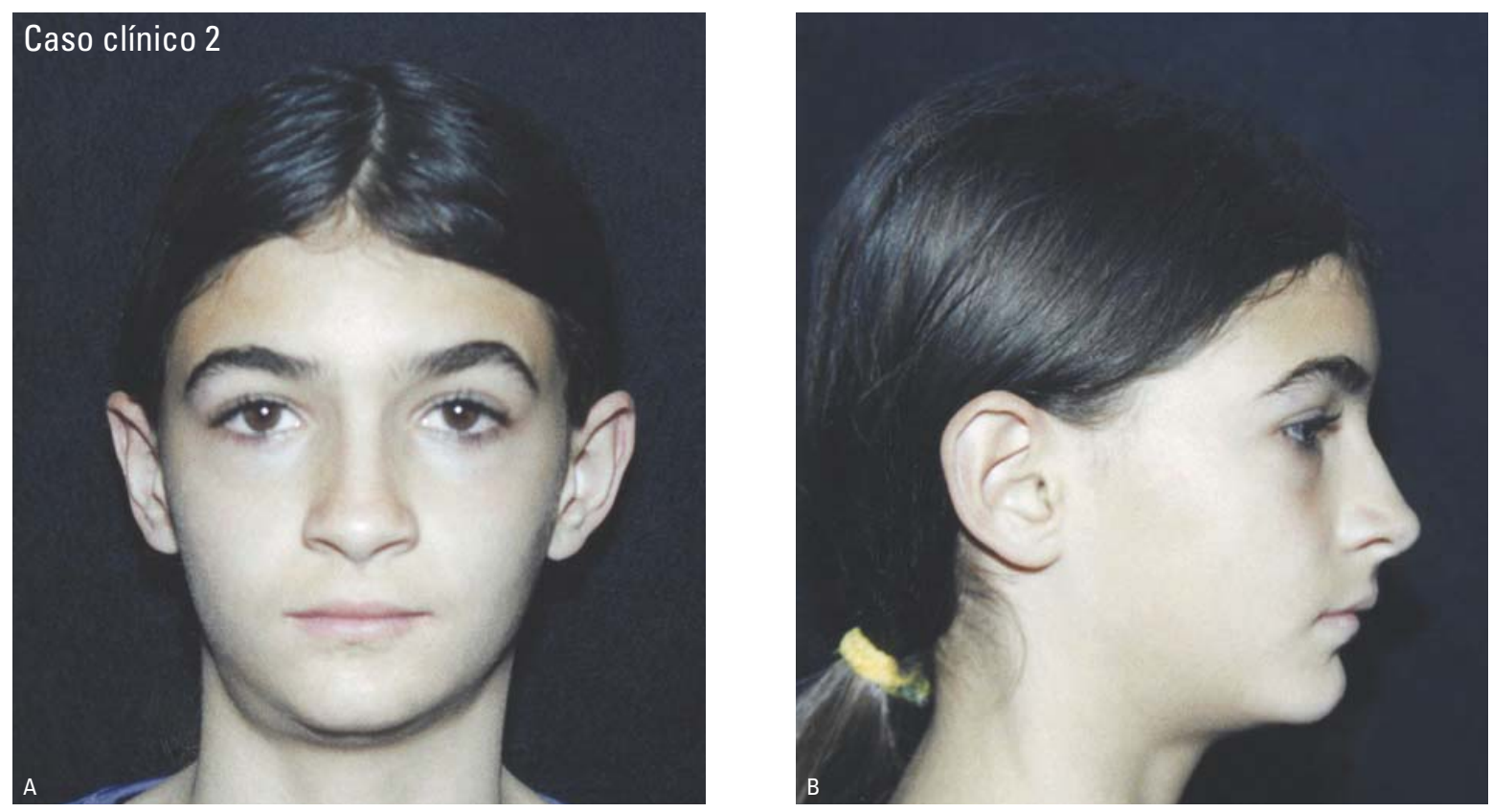

FIGURA 32 - A) Vista frontal extrabucal inicial. B) Vista lateral extrabucal inicial.
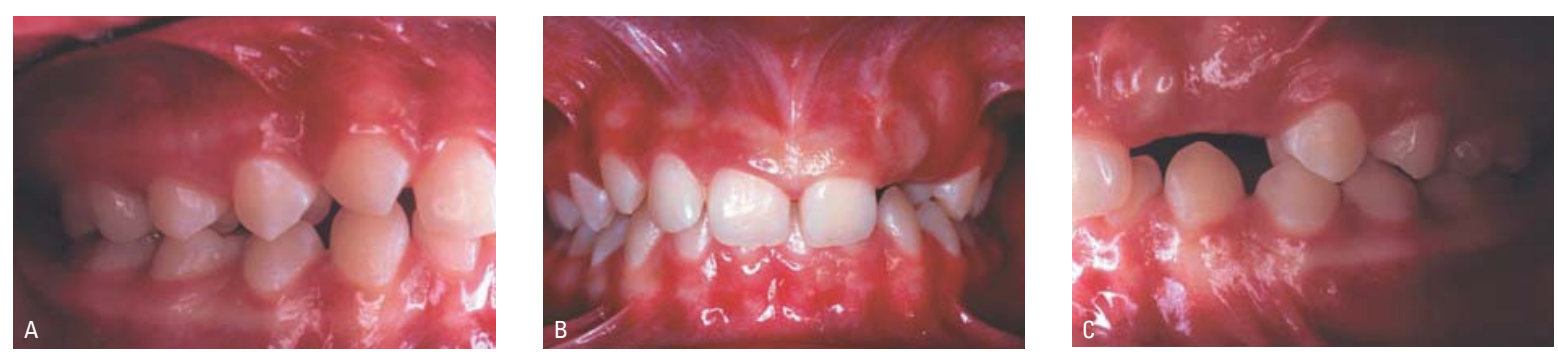

FIGURA 33 - A) Vista lateral direita intrabucal inicial. B) Vista frontal intrabucal inicial. C) Vista lateral esquerda intrabucal inicial.
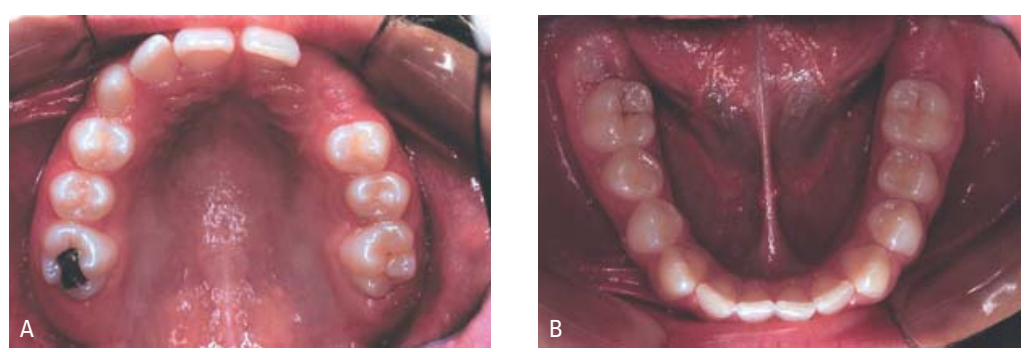

FIGURA 34 - A) Vista oclusal superior intrabucal inicial. B) Vista oclusal inferior intrabucal inicial.

mente à permanência dos dentes 55 e 75 que ainda não esfoliaram e refletem diretamente nas posições dos caninos de ambos os lados. O AEB (Kloehn) foi utilizado para auxiliar no controle e na dista- lização dos primeiros molares e ao mesmo tempo, minimizar os efeitos indesejáveis da utilização da BP. O aparelho ortodôntico corretivo foi removido prematuramente e é provável que seja remontado 


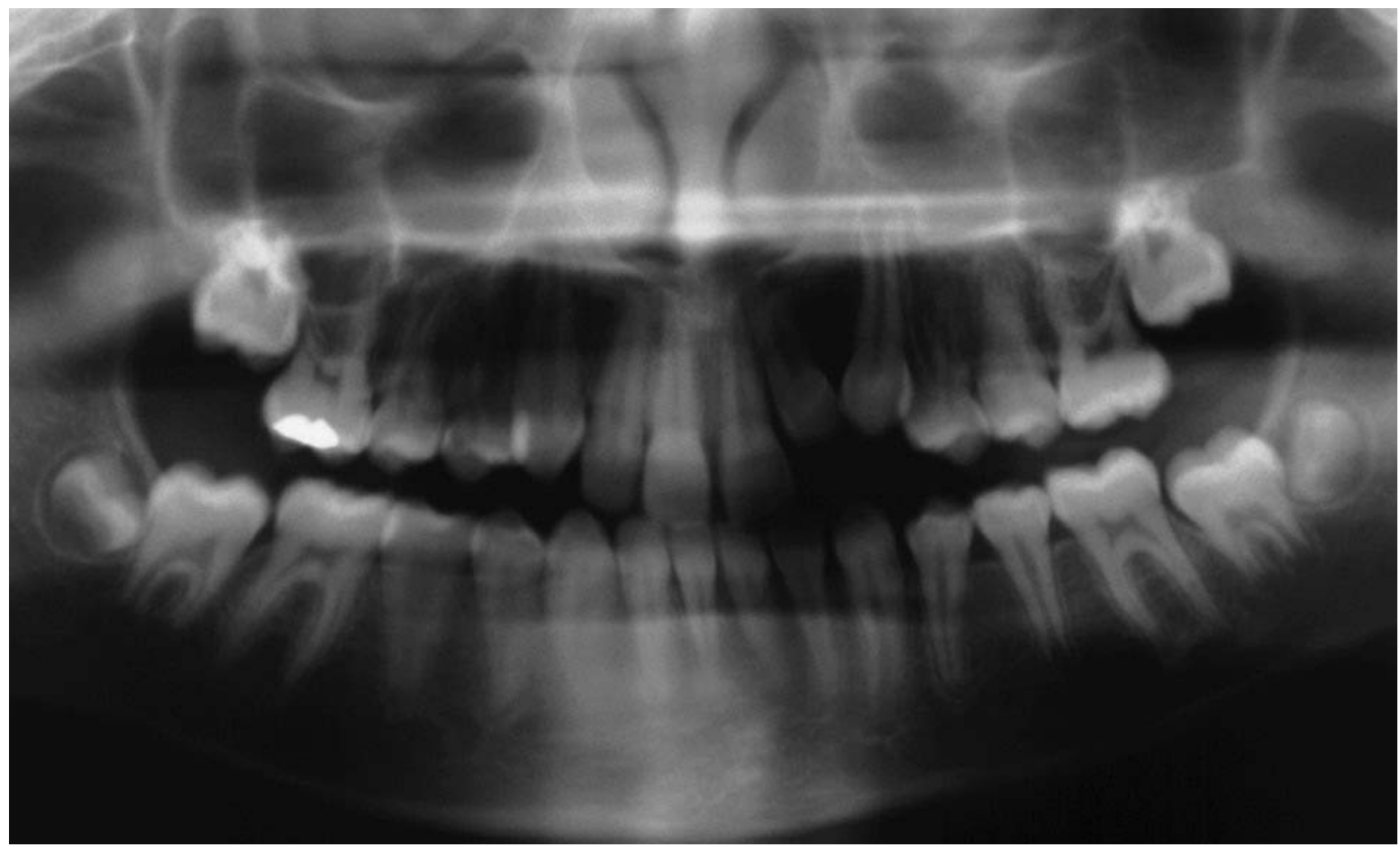

FIGURA 35 - Radiografia panorâmica inicial. Impactação dos dentes 22 e 23; dilaceração radicular do dente 22.
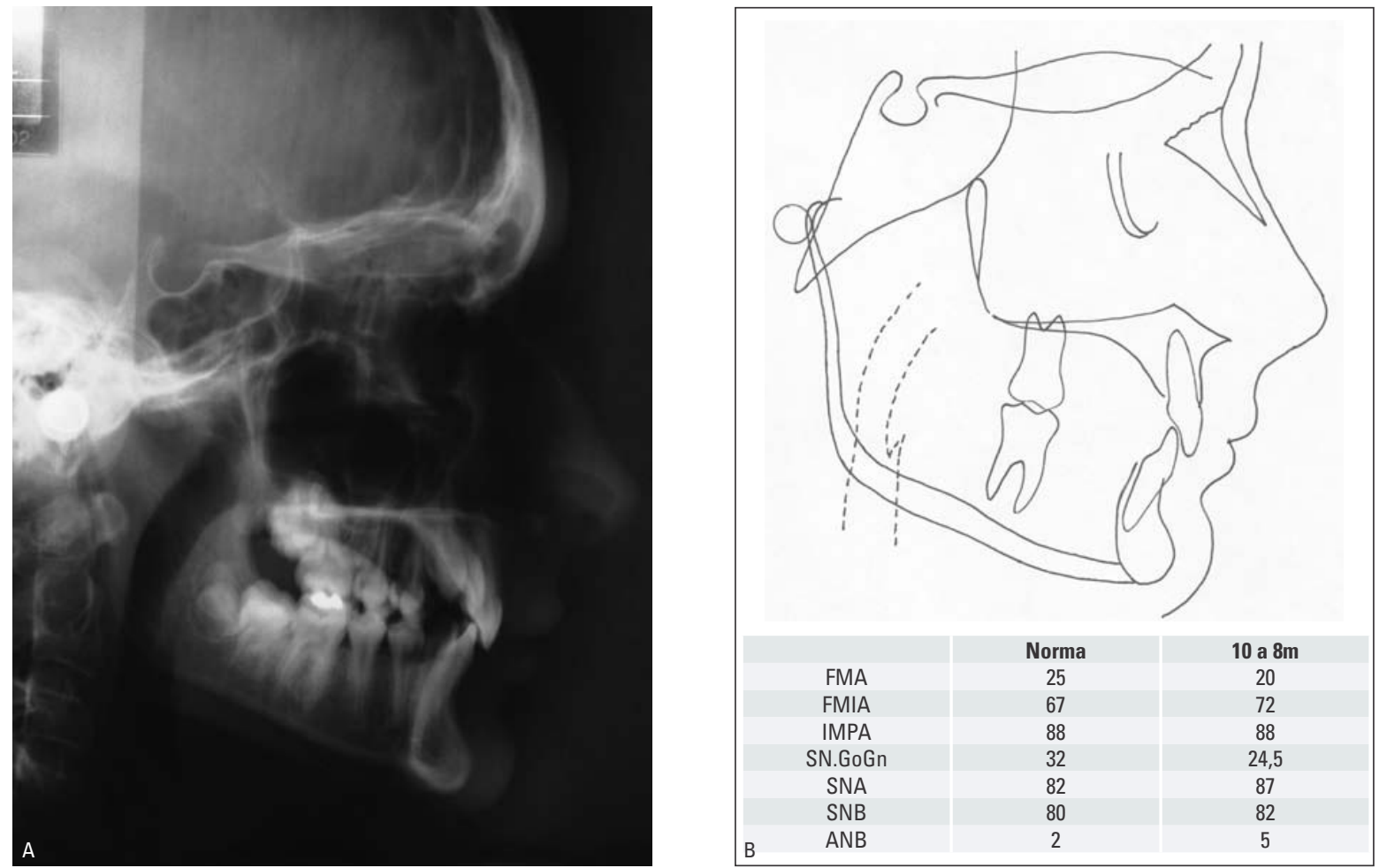

FIGURA 36 - A) Telerradiografia em norma lateral. B) Cefalograma inicial e grandezas cefalométricas iniciais. 

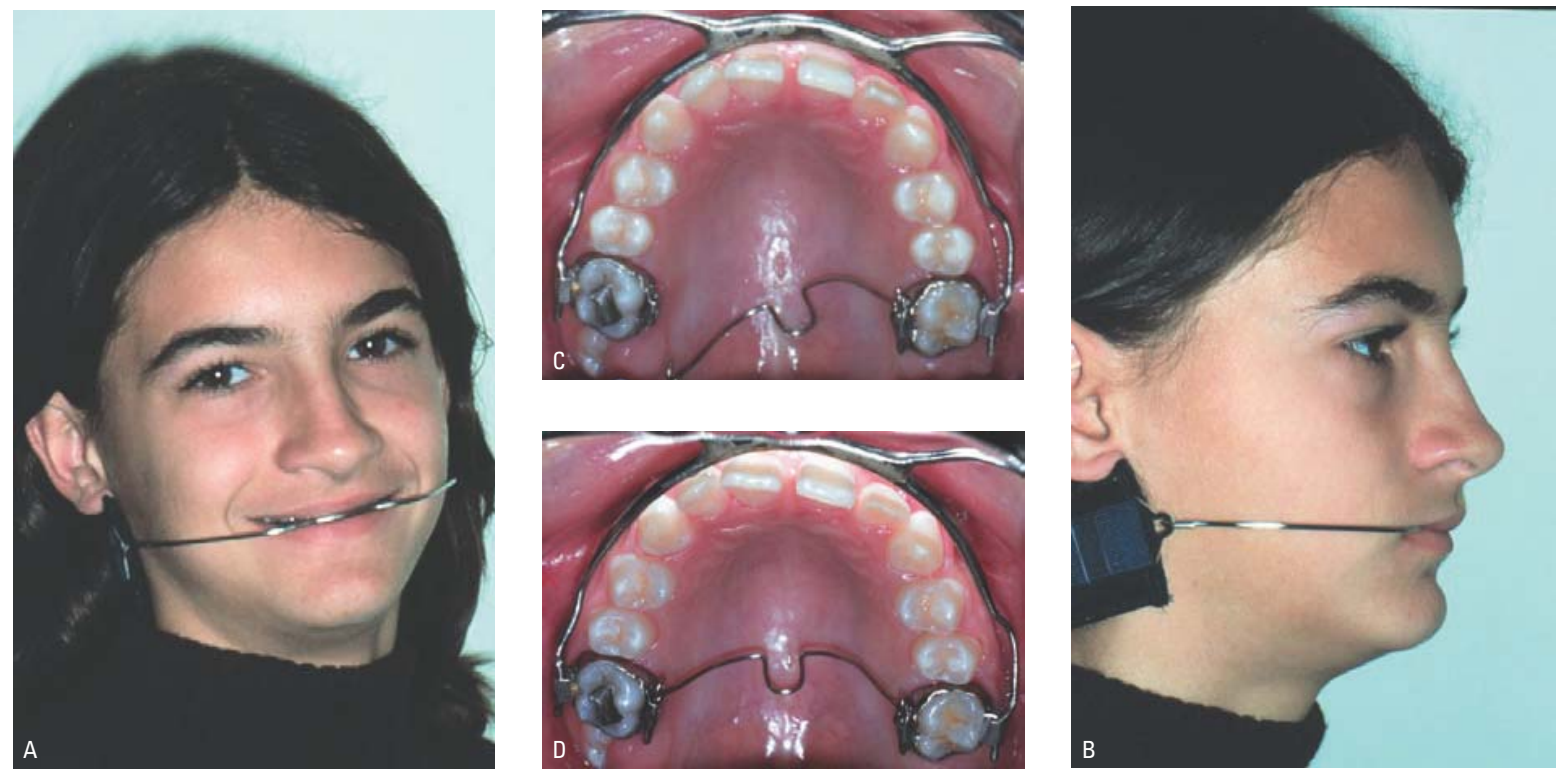

FIGURA 37 - A) Vista sorrindo extrabucal utilizando AEB (Kloehn). B) Vista lateral extrabucal utilizando AEB. C) Vista oclusal superior utilizando AEB e BP ativa. D) Vista oclusal superior utilizando AEB e BP ativada e inserida no tubo lingual.
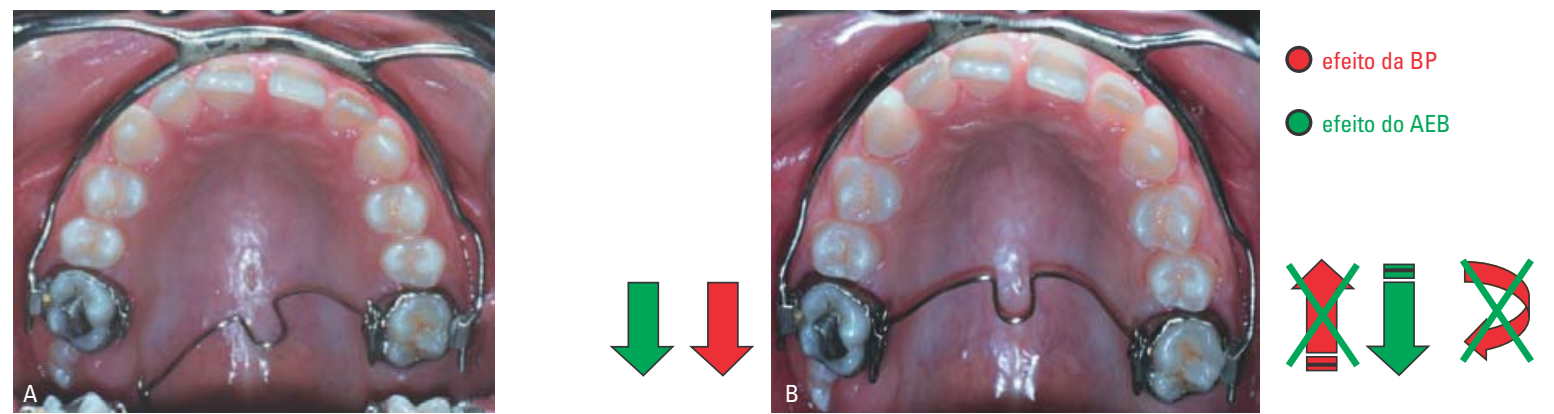

FIGURA 38 - A) Barra palatina ativa para o dente 16. B) Sistema de forças da BP ativada e inserida no tubo lingual do dente 16 e associada com o AEB.

posteriormente para o correto posicionamento dos segundos pré-molares e segundos molares superiores e inferiores, que não foram colados até a remoção do aparelho ortodôntico corretivo.

\section{Implantes para ancoragem em Ortodontia}

Atualmente a ancoragem proporcionada pelos minimplantes, miniparafusos, miniplacas e outros é uma realidade. Esses dispositivos ampliaram os horizontes do ortodontista, tornando possível, e de maneira mais eficaz, a realização de procedimentos até então limitados pela natureza da má oclusão. É possível eliminar os movimentos indesejáveis nos dentes utilizados para ancoragem, melhorando o prognóstico daquele tratamento que necessita da colaboração do paciente e há a possibilidade de gerar forças contínuas e de magnitudes ideais, otimizando o tratamento ortodôntico. Segundo Tondelli e Baggio ${ }^{41}$, os implantes demonstram ser um bom meio para promover ancoragem, principalmente nos casos que necessitam de ancoragem máxima, quando o paciente não aceita o uso de aparelho extrabucal e de ancoragem intermaxilar ou possui ausência de dentes posteriores.

Para Bae et $\mathrm{al}^{3}{ }^{3}$, os métodos convencionais de reforço de ancoragem ortodôntica apresentam des- 

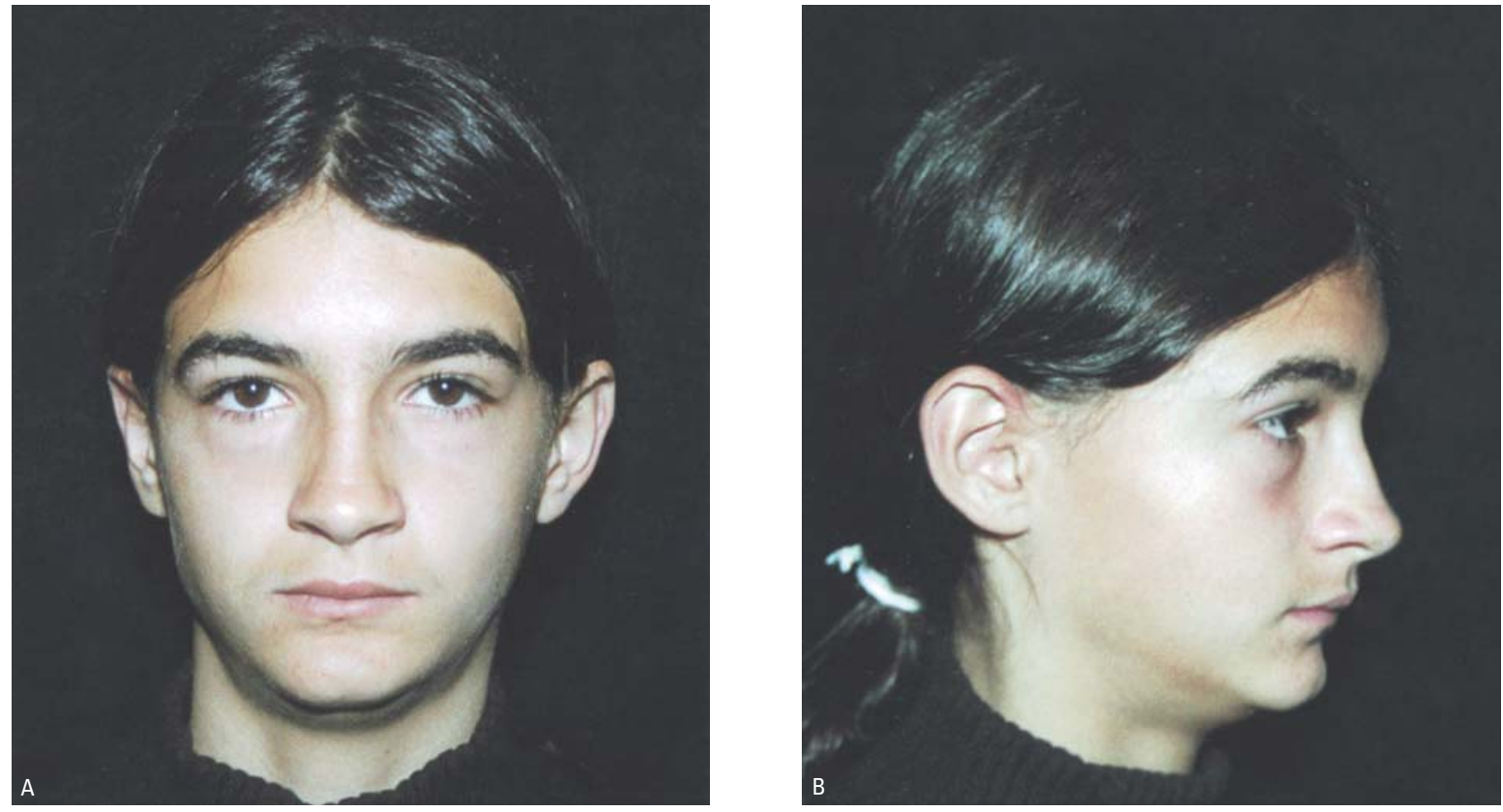

FIGURA 39 - A) Vista frontal extrabucal final. B) Vista lateral extrabucal final. Após a utilização do AEB e da BP.
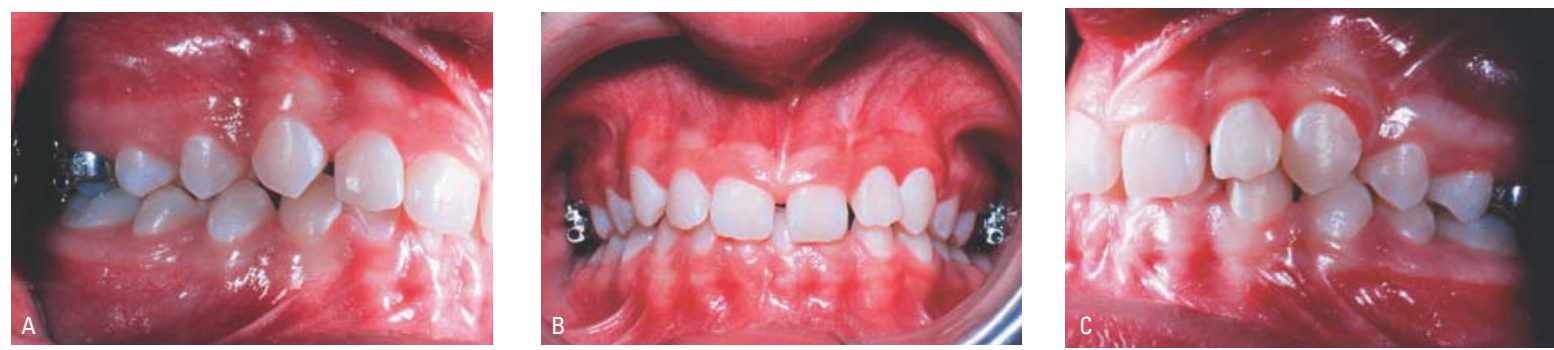

FIGURA 40 - A) Vista lateral direita intrabucal final. B) Vista frontal intrabucal final. C) Vista lateral esquerda intrabucal final. Após a utilização do AEB e da BP.

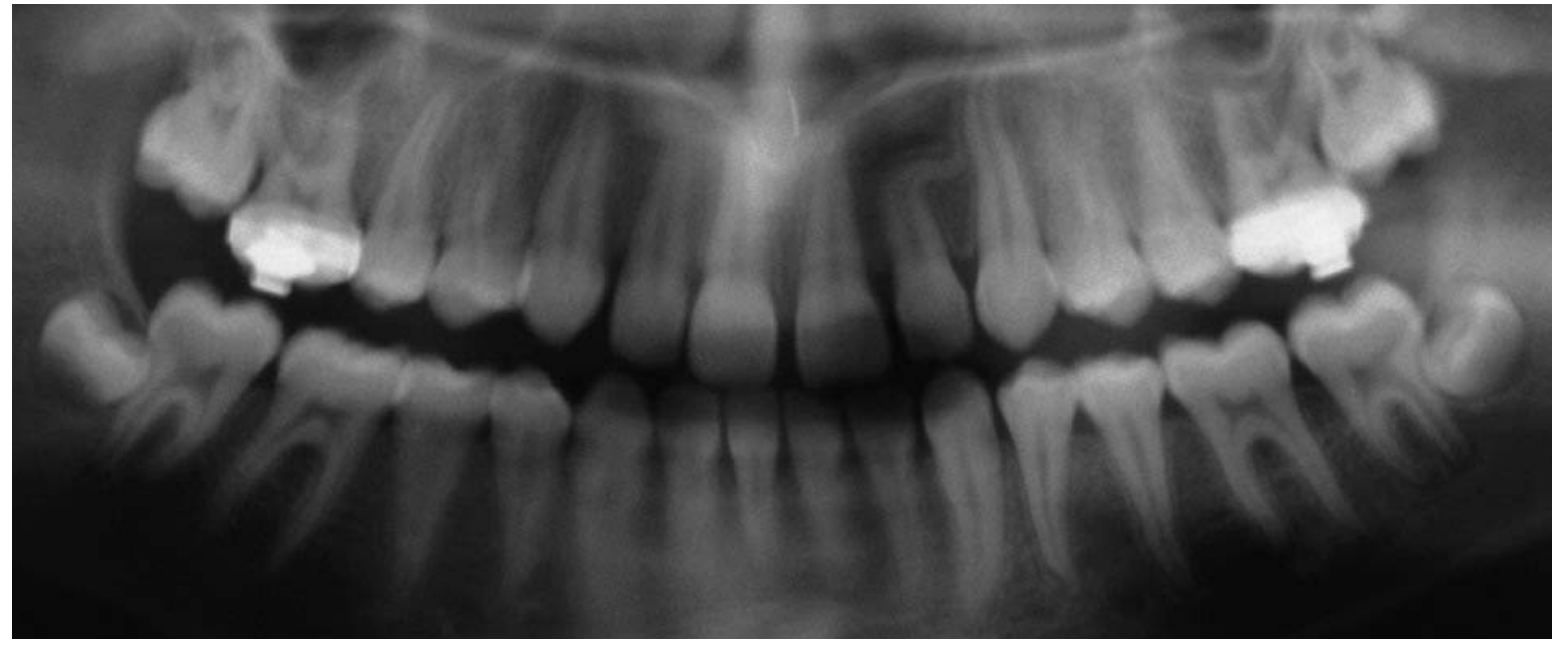

FIGURA 41 - Radiografia panorâmica final. Após a utilização do AEB e da BP. 

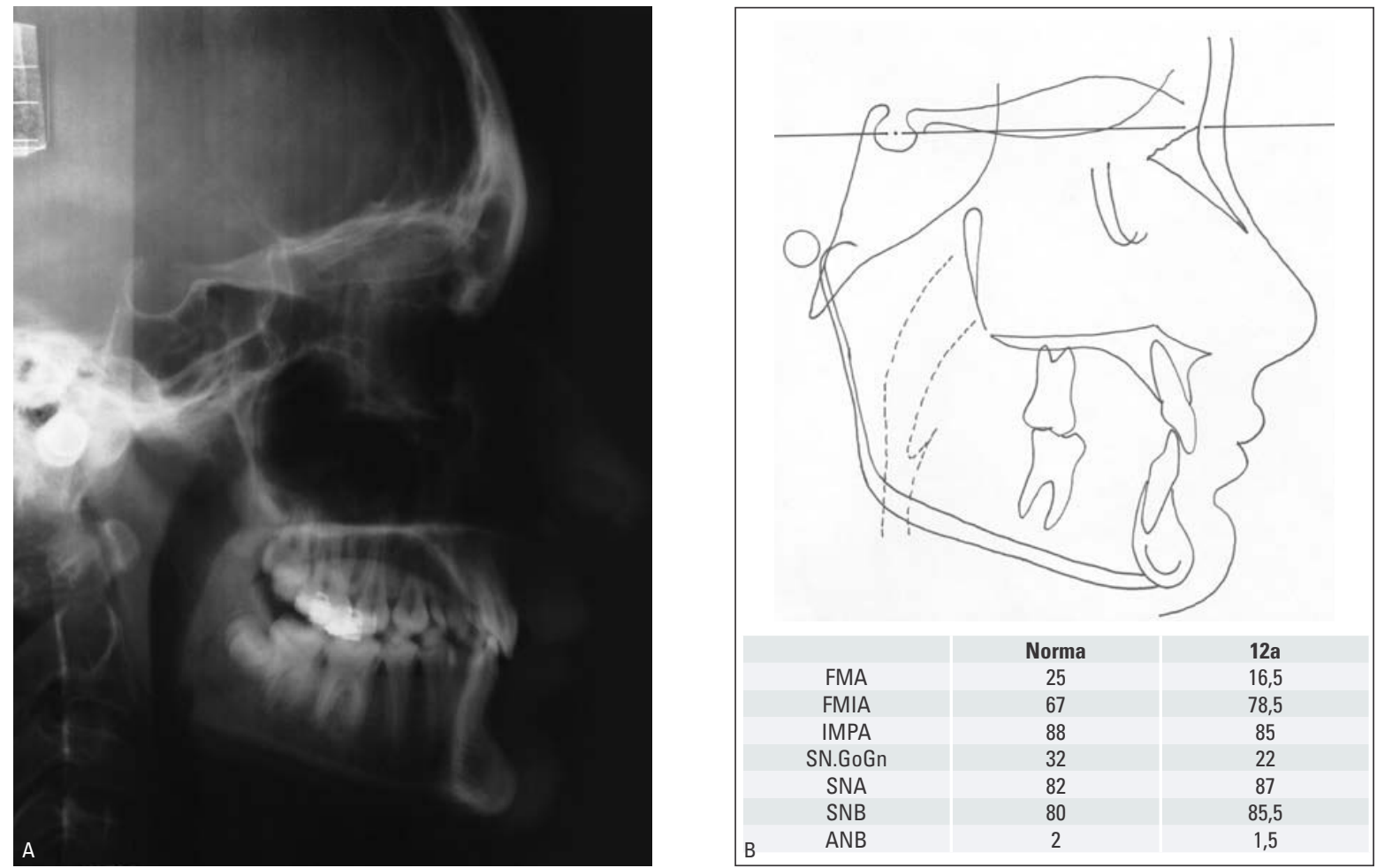

FIGURA 42 - A) Telerradiografia em norma lateral final. B) Cefalograma e grandezas cefalométricas finais. Após a utilização do AEB e da BP.

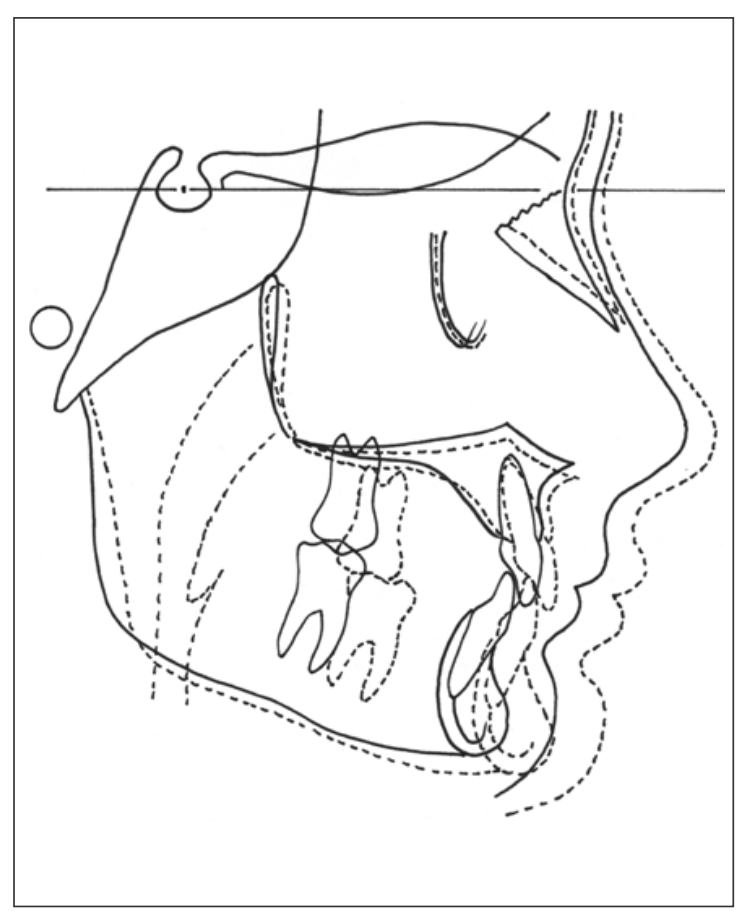

FIGURA 43 - Sobreposição total após a utilização do AEB e da BP. vantagens, incluindo aparelhos mais complexos e a necessidade de uma maior cooperação por parte dos pacientes. Segundo os autores, o minimplante apresenta baixo custo, pode ser inserido no local desejado, incluindo espaço inter-radicular, uma vez que apresenta pequeno diâmetro $(1,2 \mathrm{~mm})$. Afirmaram ainda que esse dispositivo pode receber carga imediatamente após a sua instalação e resiste a forças ortodônticas de 200 a 300 gramas, não necessitando esperar pela osseointegração e ainda podendo ser removido pelo ortodontista.

Como desvantagens desse sistema, podemos citar o comprometimento da superfície radicular que pode ocorrer durante a colocação ou durante a movimentação dos dentes adjacentes; a irritação local; o risco de infecção e alguma dificuldade de se estabelecer uma boa relação entre a linha de ação da força com o centro de resistência do dente a ser movimentado. Como desvantagem ainda, podemos destacar a limitação na alteração da discrepância 

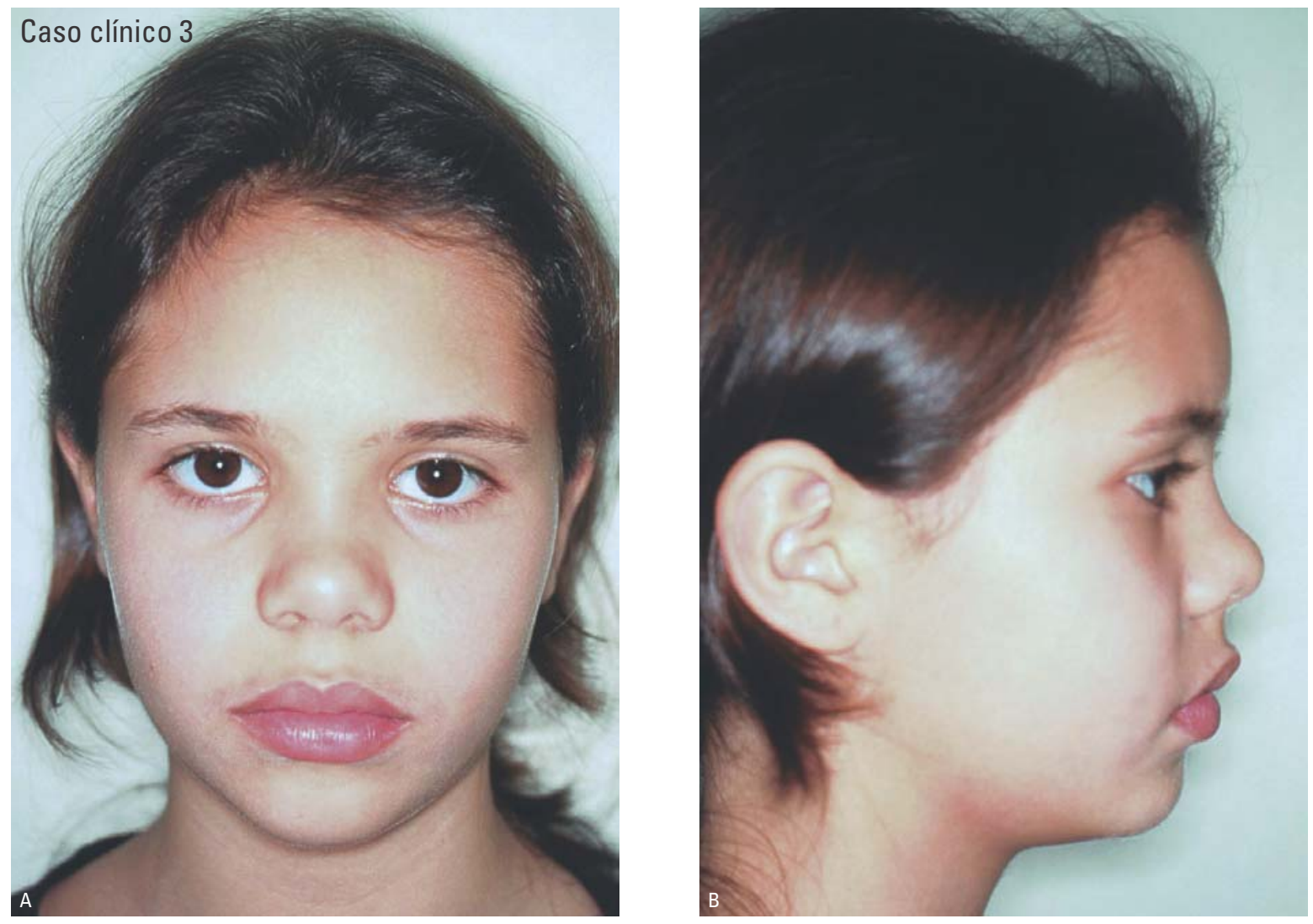

FIGURA 44 - A) Vista frontal extrabucal inicial. B) Vista lateral extrabucal inicial.
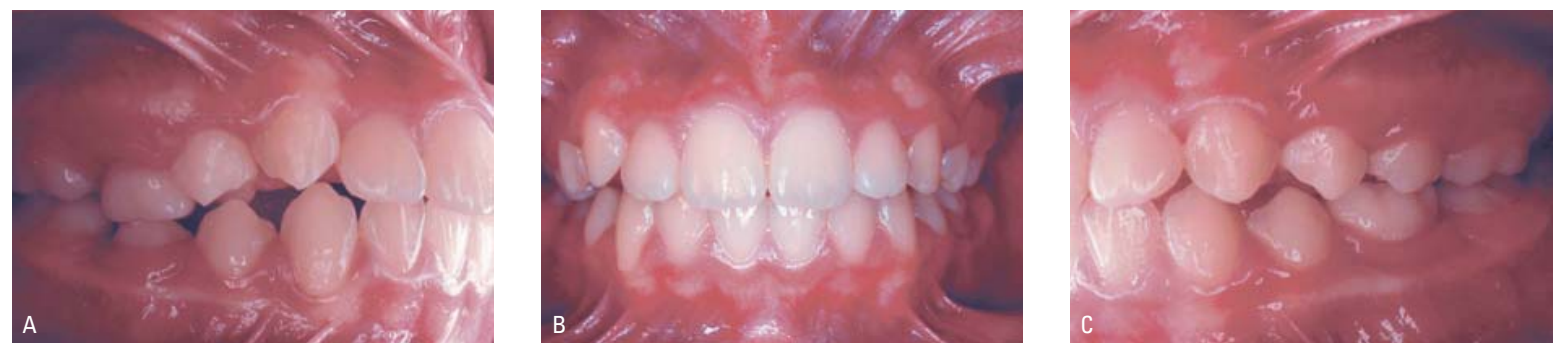

FIGURA 45 - A) Vista lateral direita intrabucal inicial. B) Vista frontal intrabucal inicial. C) Vista lateral esquerda intrabucal inicial.
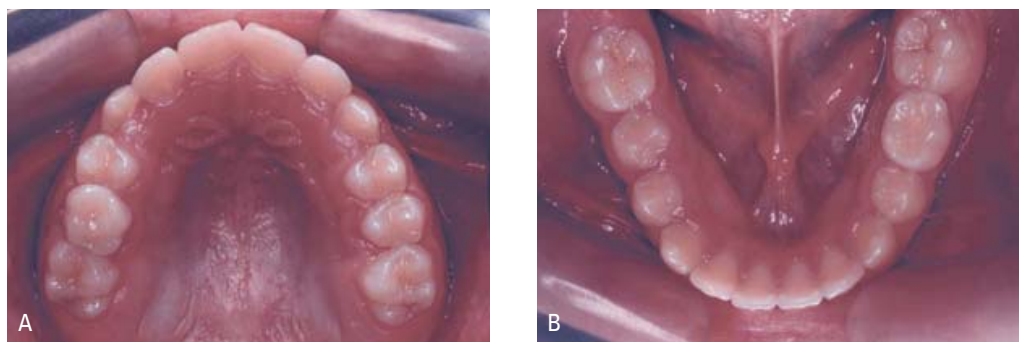

FIGURA 46 - A) Vista oclusal superior intrabucal inicial. B) Vista oclusal inferior intrabucal inicial. 

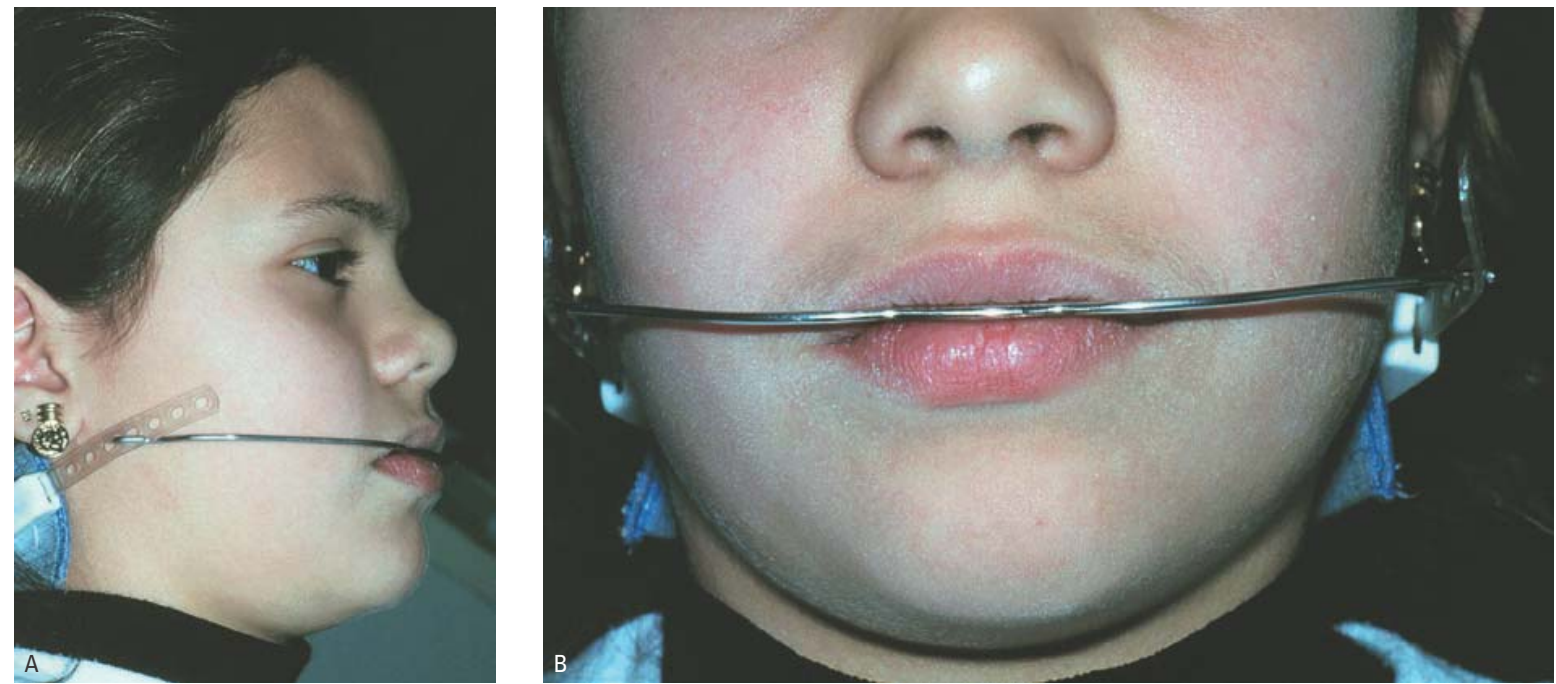

FIGURA 47 - A) Vista lateral extrabucal utilizando AEB (Kloehn). B) Vista frontal aproximada extrabucal utilizando AEB (Kloehn).
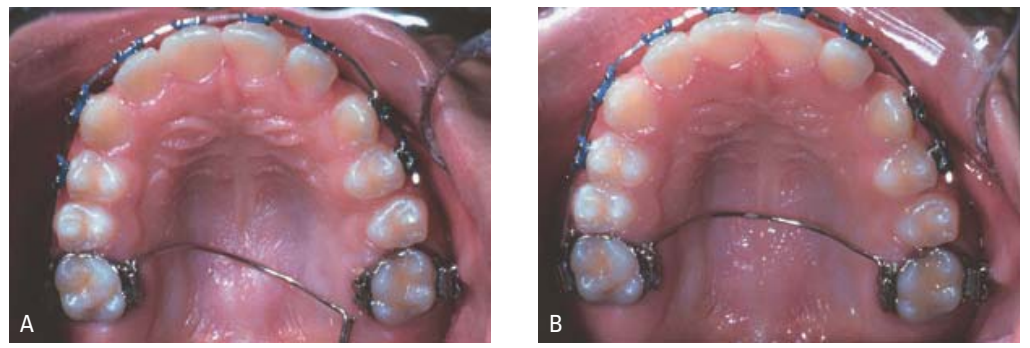

FIGURA 48 - A) Vista oclusal superior intrabucal utilizando BP ativa. B) Vista oclusal superior intrabucal utilizando BP ativada e inserida no tubo lingual.

esquelética da má oclusão Classe II de Angle que, conforme a situação, é solucionado de maneira mais eficaz aplicando-se uma força extrabucal.

\section{CONSIDERAÇÕES FINAIS}

Os implantes preconizados para ancoragem não substituem a utilização do AEB - ambos possuem vantagens e desvantagens, cada qual com suas aplicações precisas. Certamente a utilização dos miniparafusos, dos minimplantes e das miniplacas possibilitou ao ortodontista transpor paradigmas e limitações inerentes ao tratamento ortodôntico convencional. E com a evolução dos materiais empregados para a construção desses dispositivos, bem como com a aplicação de novos conceitos biomecânicos, algumas dificuldades ainda deverão ser superadas, e, cada vez mais, os minimplantes serão aplicados nas resoluções das mais diversas maloclusões.

E para finalizar esse trabalho, algumas considerações serão realizadas. Dentre as possivieis filosofias para o tratamento da má oclusão de Classe II de Angle, a utilização do aparelho extrabucal tem se mostrado bastante eficaz e seus resultados são os mais expressivos no sentido de corrigir a discrepância ântero-posterior maxilo-mandibular ${ }^{8,15,45}$.

No entanto, para que isso ocorra, os conceitos biomecânicos devem estar bem sedimentados e serem aplicados. $\mathrm{O}$ arco externo deve ser ajustado de acordo com fatores como os centros de resistência da maxila, da dentição ou do dente a ser distalizado e a linha de ação de força ${ }^{25,34}$. 

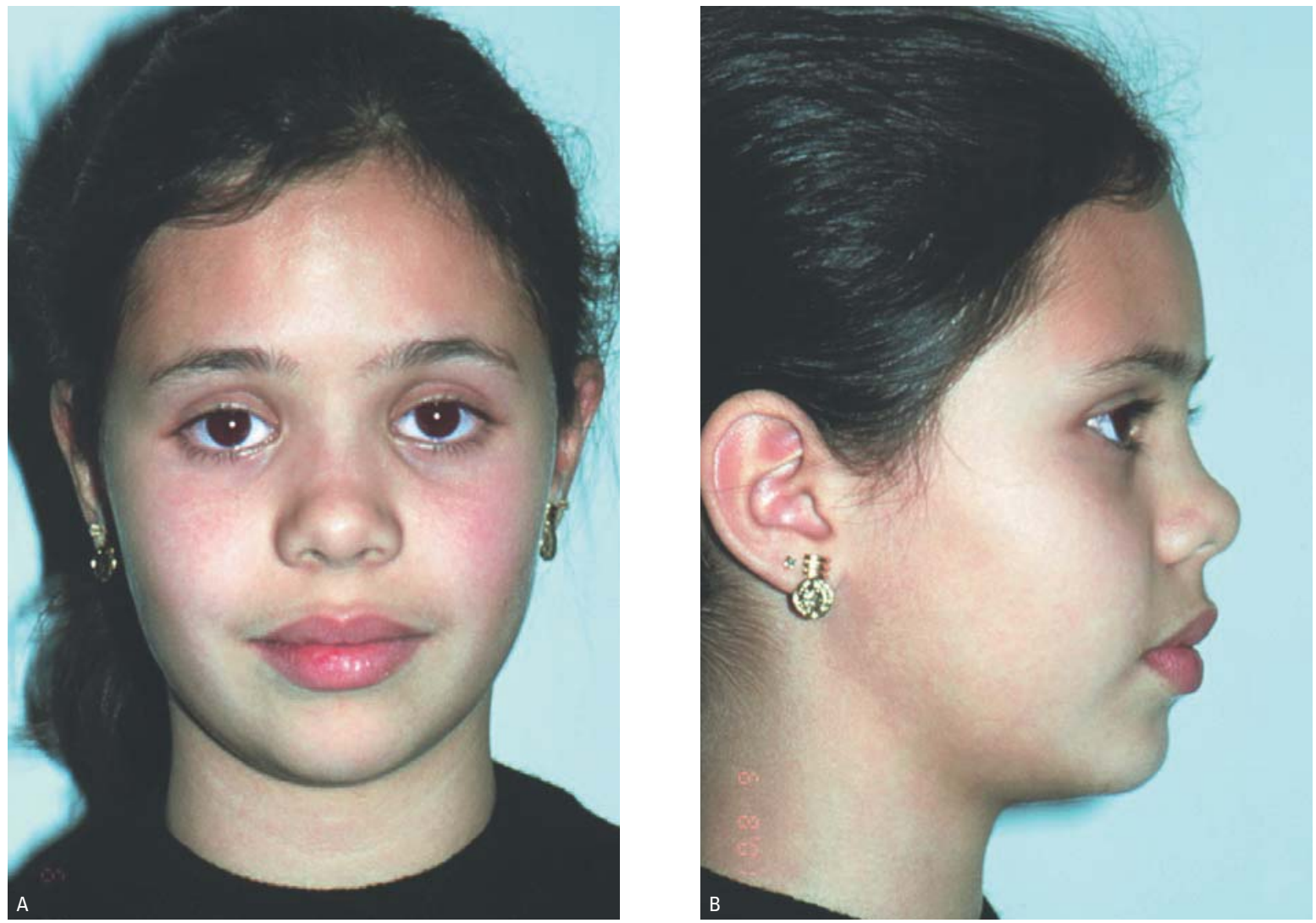

FIGURA 49 - A) Vista frontal extrabucal. B) Vista lateral extrabucal. Após a primeira fase do tratamento (utilização do AEB e da BP).
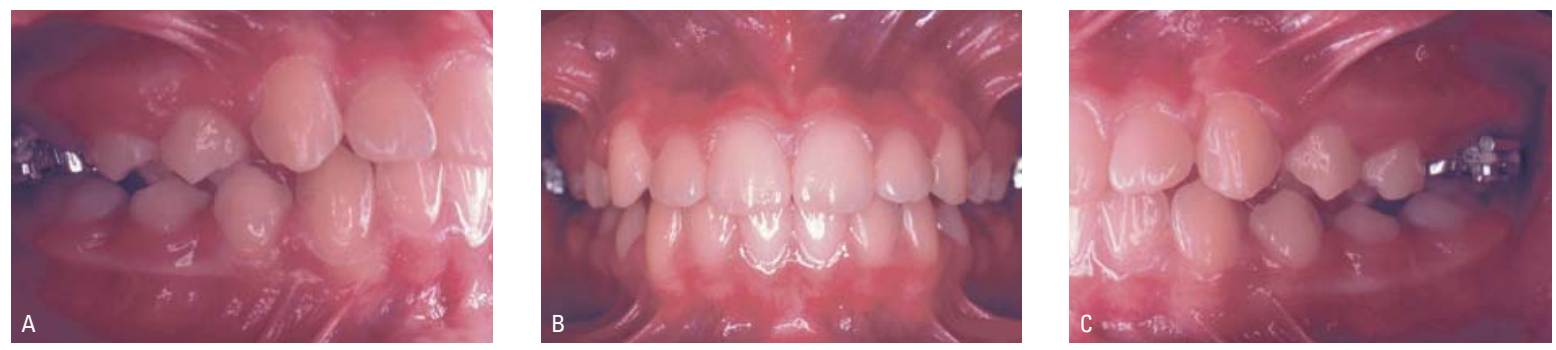

FIGURA 50 - A) Vista lateral direita intrabucal. B) Vista frontal intrabucal. C) Vista lateral esquerda intrabucal. Após a primeira fase do tratamento (utilização do AEB e da BP).
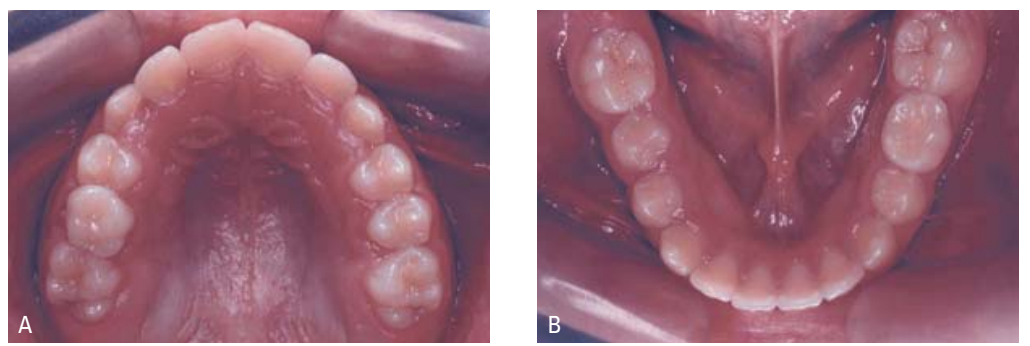

FIGURA 51 - A) Vista oclusal superior intrabucal. B) Vista oclusal inferior intrabucal. Após a primeira fase do tratamento (utilização do AEB e da BP). 

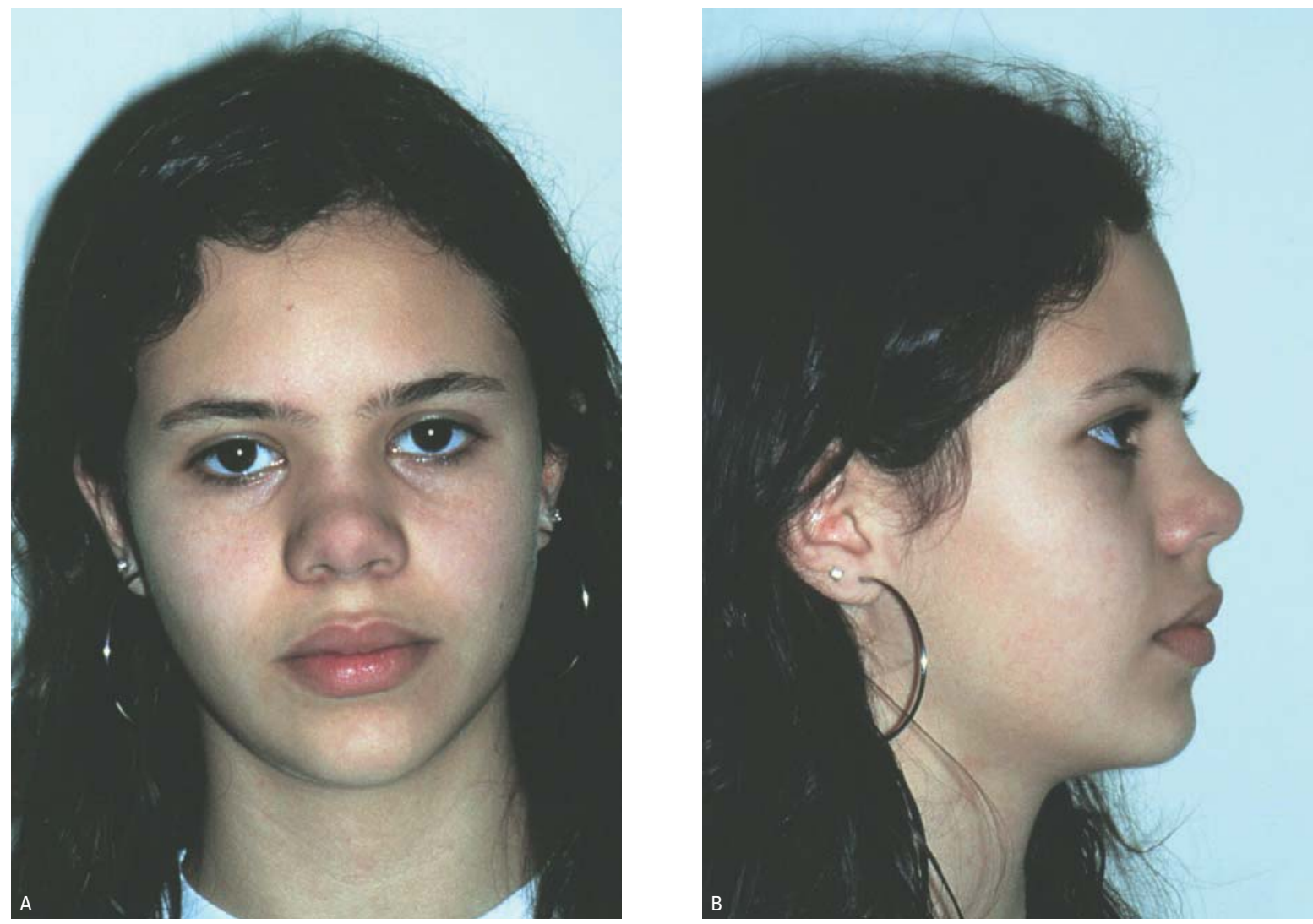

FIGURA 52 - A) Vista frontal extrabucal final. B) Vista lateral extrabucal final.
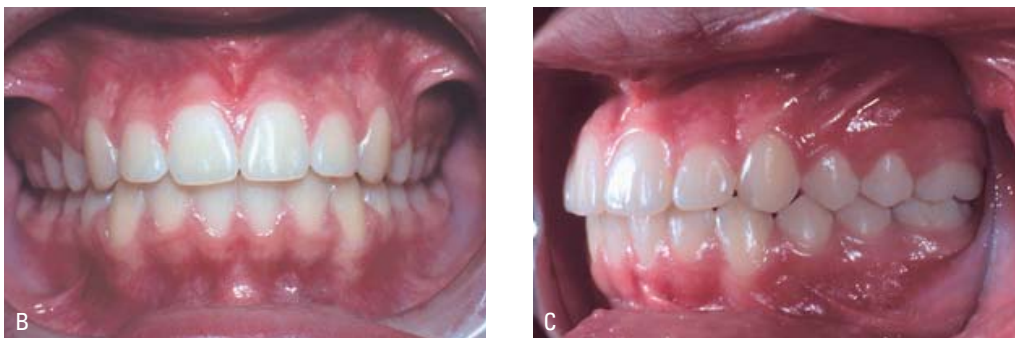

FIGURA 53 - A) Vista lateral direita intrabucal final. B) Vista frontal intrabucal final. C) Vista lateral esquerda intrabucal final.
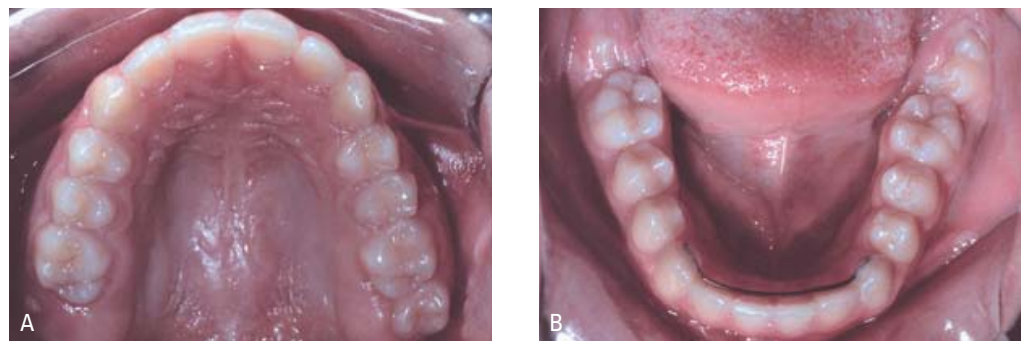

FIGURA 54 - A) Vista oclusal superior intrabucal final. B) Vista oclusal inferior intrabucal final. 

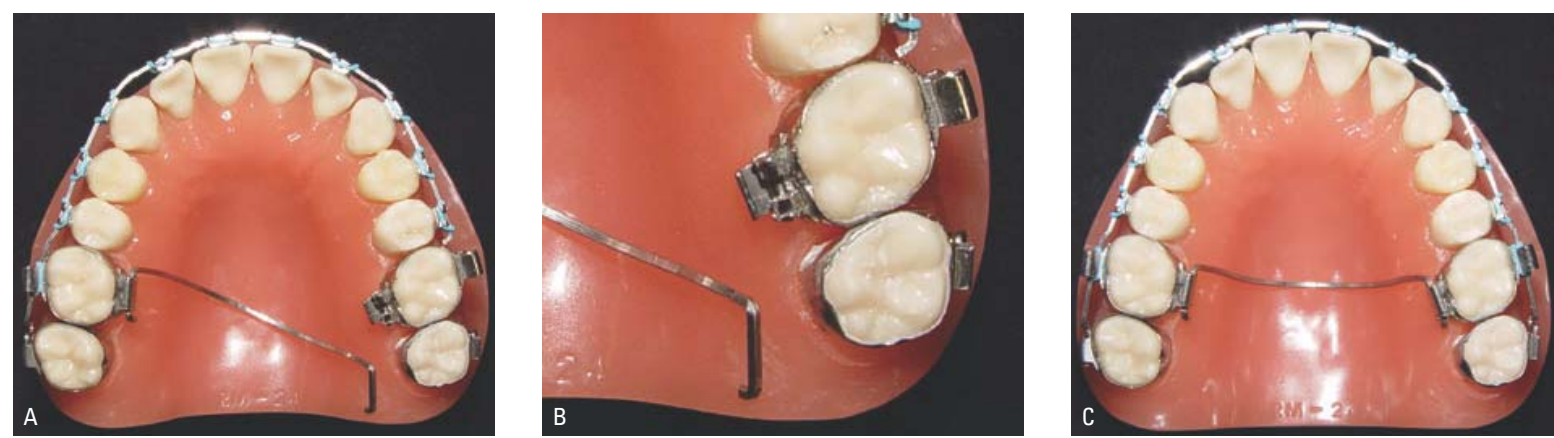

FIGURA 55 - Barra palatina construída com fio beta-titânio (TMA) 032" x .032" (Ormco). A) Ativação da BP para distalização do dente 26. B) Detalhe do encaixe hing cap (Ormco) para inserção da extremidade da BP. C) Barra palatina ativada e posicionada na arcada superior.
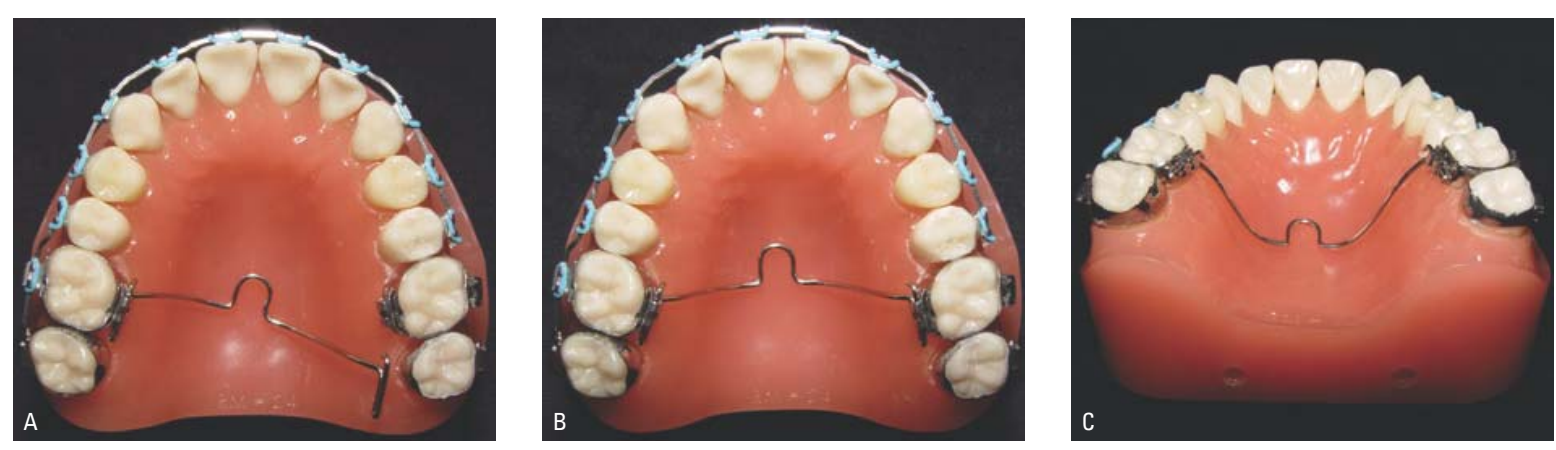

FIGURA 56 - Barra palatina construída com fio de aço inoxidável 0,8 mm. A) Ativação da BP para distalização do dente 26. B) Inserção da presilha no tubo lingual 20.60.100 (Morelli Ortodontia). C) Adaptação da BP no contorno do palato.

Para Barton ${ }^{4}$, Oosthuizen, Dijkman e Evans ${ }^{34}$ e Jacobson ${ }^{25}$ a existência de diferentes tipos de tração, tais como, baixa, média e alta e diferentes comprimentos de arco externo, como curto, médio ou longo, cria inúmeras possibilidades de utilização de forças, cada uma produzindo um efeito diferente. Isso ocorre porque a linha da ação de força interage com os centros de resistência, da dentição e da maxila, proporcionando movimentos de rotação ou de translação. A melhor ação ocorreria se a linha de ação de força passasse entre o CResM e o CResD, pois assim as rotações seriam minimizadas, bem como as interferências na dentição. Se, por exemplo, a linha de ação de força passar abaixo dos dois centros de resistência, pode-se produzir uma excessiva rotação horária, pois ocorre uma somatória dos momentos ${ }^{40}$.

Em um indivíduo com padrão de crescimento vertical, todo cuidado deve ser tomado para que não se produza excessiva rotação horária, pois seus efeitos seriam a abertura da mordida e conseqüente piora no padrão de crescimento7, 11,33. Nos indivíduos braquifaciais, alguma rotação pode até melhorar o perfil e, se houver sobremordida profunda, melhorá$1 \mathrm{a}^{38}$. Em indivíduos mesofaciais, a tração baixa também pode ser utilizada, trazendo resultados bastante satisfatórios. A tração média está indicada para aqueles casos clínicos em que não se deseja movimentos de extrusão e nem de intrusão dentária.

O importante é avaliar os tipos de movimentos que determinada linha de ação de força produzirá em cada paciente. A avaliação individual considerando o padrão de crescimento, as necessidades de movimentos extrusivos, intrusivos ou nenhum deles, bem como a verificação do perfil e as alterações verticais são maneiras de se estabelecer qual é o melhor ajuste do aparelho extrabucal. Além disso, de acordo com a literatura citada, a influência das forças ex- 
trabucais nas estruturas circundantes existe, e algum tipo de previsão também pode ser feito.

A magnitude de força aplicada é um fator determinante na utilização do aparelho extrabucal, uma vez que precisa ser suficiente para que as alterações sejam tanto ortopédicas quanto ortodônticas, ou seja, que atuem em suturas e estruturas ósseas bem como em processos alveolares ${ }^{8}$.

A época em que o tratamento com aparelho extrabucal é aplicado pode ser tanto em uma fase precoce, ou seja, durante a dentição mista, quanto tardia, no início da dentição permanente. Inúmeros estudos verificaram que os resultados são basicamente os mesmos, no entanto quando em uma fase tardia, os custos e os desgastes do paciente são redu- zidos, pois o tempo total de tratamento é menor ${ }^{43}$.

Enfim, para que o tratamento com o aparelho extrabucal obtenha os resultados esperados, uma série de fatores deve ser rigorosamente observada. Fatores estes, como por exemplo, o tipo de puxada, a inclinação e o comprimento do arco externo do aparelho extrabucal, bem como a linha de ação de força, a idade esquelética do paciente, a magnitude de força e o tempo de uso diário do aparelho. Desta maneira, rotações indesejáveis podem ser evitadas, movimentos dentários ou ortopédicos dos maxilares podem ser planejados, bem como influências sobre o plano mandibular e sobre o padrão de crescimento do paciente podem ser monitorados/controlados.

\title{
Biomechanic principles of the headgear appliance
}

\begin{abstract}
The use of the headgear appliance for the treatment of Angle Class II malocclusion demands that the biomechanic principles are understood and applied so that the clinic case is conducted in a way that the side effects are minimized and the benefits maximized. Therefore, the orthodontist must be able to predict the effects of the inclination of the line of traction and its relation to the teeth and maxillary centers of resistance. Any rotation movement, inclination or translation of the teeth and maxillary and mandibular rotation clockwise or counter clockwise can be predict and planned when the orthodontist knows the mechanism that cause them, as well as the effects that the different types of traction produce in subjects with dolichofacial, mesofacial or brachyfacial types. Thus, the aim of this work is to present predominant and indispensable factors for the utilization of the headgear appliance for the treatment of Angle Class II malocclusion.
\end{abstract}

Key words: Angle Class II malocclusion. Extraoral traction appliances. Orthodontic treatment. Biomechanics.

\section{REFERÊNCIAS}

1. ARAS, A. Class II correction with the modified sagittal appliance and maxillary second molar extraction. Angle Orthod, St. Louis, v. 70 , no. 4 , p. 332-338, Feb. 2000

2. ASHMORE, J. L. et al. A 3-dimensional analysis of molar movement during headgear treatment. Am J Orthod Dentofacial Orthop, St. Louis, v.121, no.1, p.18-30, Jan. 2002.
3. BAE, S. M.; PARK, H. S.; KYUNG, H. M.; KWON, O. W.; SUNG, J. H. Aplicação clínica dos microimplantes para ancoragem. Rev Dental Press Ortodon Ortop Facial, Maringá, v. 2, n. 5, p. 298-232, fev./mar. 2003.

4. BARTON, J. J. High-pull headgear versus cervical traction: a cephalometric comparison. Am J Orthod, St. Louis, v. 62, no. 5, p. 517-529, Nov. 1972. 
5. BAPTISTA, J. M. Ortodontia personalizada. 1. ed. São Paulo: Ed. Santos, 2004

6. BAUMRIND, S.; MOLTHEN, R.; WEST, E.; MILLER, D. Distal displacement of the maxilla and upper first molar. Am J Orthod, St. Louis, v. 75, no. 6, p. 630-640, June 1979.

7. BAUMRIND, S.; KORN, E. L.; MOLTHEN, R.; WEST, E. Changes in facial dimensions associated with the use of forces to retract the maxilla. Am J Orthod, St. Louis, v. 80, no.1, p.17-30, July 1981.

8. BAUMRIND, S; KORN, E. L.; ISAACSON, R. J.; WEST, E.; MOLTHEN, R. Quantitative analysis of the orthodontic and orthopedic effects of maxillary traction. Am J Orthod, St. Louis, v. 78, p. 384-398, Nov. 1983

9. BISHARA, S.E. Mandibular changes in persons with untreated and treated class II division 1 malocclusion. Am J Orthod Dentofacial Orthop, St. Louis, v.113, no. 6, p. 661-673, June 1998.

10. BISHARA, S. E.; JAKOBSEN, J. R. Longitudinal changes in three normal facial types. Am J Orthod, St. Louis, v. 88, no. 6, p. $466-$ 502, Dec. 1985

11. BLUEHER, W. A. Cephalometric analysis of treatment with cervical anchorage. Angle Orthod, Appleton, v. 29, no.1, p. 45-53, Jan. 1959.

12. BROWN, P. A cephalometric evaluation of high-pull molar headgear and face-bow neck strap therapy. Am J Orthod, St. Louis, v. 74, no. 6, p. 621-632, Dec. 1978

13. CETLIN, N. M.; TEN HOEVE, A. Non extraction treatment. J Clin Orthod, Boulder, v.17, p. 396-413, 1983.

14. CREEKMORE, T. D. Inhibition or stimulation of the vertical growth of the facial complex, its significance to treatment. Angle Orthod, Appleton, v. 37, no. 4, p. 285-297, Oct. 1967.

15. DEVINCENZO, J. P.; WINN, M. W. Orthopedic and orthodontic effects resulting from the use of a functional appliance with different amounts of protrusive activation. Am J Orthod Dentofacial Orthop, St. Louis, v. 96, no. 3, p.181-190, Sept. 1989.

16. ENLOW, D. W. Crescimento facial. 3. ed. São Paulo: Artes Médicas, 1993.

17. GANDINI JÚNIOR, L. G. et al. Avaliação cefalométrica do tratamento da Classe II, Divisão 1a, com aparelho extrabucal de Kloehn, aparelho fixo: alterações esqueléticas. Parte I. Rev Dental Press Ortodon Ortop Facial, v. 2, n. 6, p. 75-87, nov./dez. 1997.

18. GANDINI, M. R. E. A. et al. Effects of cervical headgear and edgewise appliances on growing patients. Am J Orthod Dentofacial Orthop, St. Louis, v.119, no. 5, p. 531-538, May 2001.

19. GHAFARI, J.; SHOFER, F. S.; JACOBSSON-HUNT, D. L.; MAKOWITZ, D. L. Headgear versus function regulator in the early treatment of class II, division 1 malocclusion: a randomized clinical trial. Am J Orthod Dentofacial Orthop, St. Louis, v.113, no.1, p. 51-61, Jan. 1998

20. GRABER, T. M. Extraoral force: facts and fallacies. Am J Orthod, St. Louis, v. 41, p. 262-278, July 1955.

21. GÜRAY, E.; ORHAN, M. Em masse retraction of maxillary anterior teeth with anterior headgear. Am J Orthod Dentofacia Orthop, St. Louis, v.112, no. 5, p. 473-479, Nov. 1997.

22. HARVOLD, E. P.; VARGERVIK, K. Morphogenetic response to activator treatment, Am J Orthod, St. Louis, v. 60, no. 5, p. 478 490, Nov. 1971

23. HERSHEY, H. G.; HOUGHTON, C. W.; BURSTONE, C. J. Unilateral face-bows: a theoretical and laboratory analysys. Am J Orthod, St. Louis, v. 79, no. 3, p. 229-249, 1981

24. HILGERS, J. J. The pendulum appliance for class II non-compliance therapy. J Clin Orthod, Boulder, v. 26, p. 706-714, Nov. 1992.

25. JACOBSON, A. A key to the understanding of extraoral forces. Am J Orthod, St. Louis, v. 75, no. 4, p. 361-386, Apr. 1979.
26. KEELING, S. D. et. al. Anteroposterior skeletal and dental changes after early Class II treatment with bionators and headgear. Am J Orthod Dentofacial Orthop, St. Louis, v. 114, no.1, p. 40-50, Jan. 1998

27. KLOEHN, S. J. Guiding alveolar growth and eruption of teeth to reduce treatment time and produce a more balanced denture and face. Angle Orthod, Appleton, v. 17, no. 33, p. 15-18, 1947.

28. KOPECKY, G. R.; FISHMAN, L. S. Timing of cervical headgear treatment based on skeletal maturation. Am J Orthod, v.104, no. 8, p.162-169, Aug. 1993.

29. LANGLADE, M. Terapêutica ortodôntica. 3. ed. São Paulo: Ed. Santos, 1993.

30. LUNDSTRÖM, A. Introducción a la Ortodoncia. Buenos Aires: Ed. Munch, 1971.

31. MELSEN, B. Effect of cervical anchorage during and after treatment: an implant study. Am J Orthod, St. Louis, v. 73, no. 5 p. 526-540, May 1978.

32. MELSEN. B.; BONETTI, G.; GIUNTA, D. Statically determinate transpalatal arches. J Clin Orthod,Boulder, v. 28, no.10, p. 602 606, 1994.

33. O'REILLY, M. T.; NANDA, S. K.; CLOSE, J. Cervical and oblique headgear: A comparison of treatment effects. Am J Orthod Dentofacial Orthop, St. Louis, v. 104, no. 6, p. 504-509, June 1993.

34. OOSTHUIZEN, L.; DIJKMAN, J. F. P.; EVANS, W. G. A mechanical appraisal of the Kloehn extraoral assembly. Angle Orthod, Appleton, v. 43, no. 3, p. 221-232, July 1973.

35. PROFFIT, W. R.; FIELDS JUNIOR, H. W. Ortodontia contemporânea. 3. ed. Rio de Janeiro: Guanabara-Koogan, 2002

36. RAMOS, A. L.; SAKIMA, M.T.; SANTOS-PINTO, A.; MARTINS L. P.; RAVELI, D. B. Barra Palatina. Rev Dental Press Ortodon Ortop Facial, Maringá, v. 5, n.1, p. 75-100, jan./fev. 2000.

37. RICKETTS, R. M. The influence of Orthodontic treatment on facial growth and development. Angle Orthod, Appleton, v. 30, p.103-131, 1960.

38. SCHUDY, F. F. The rotation of the mandible resulting from growth: its implications in orthodontic treatment. Angle Orthod Appleton, v. 35, no.1, p. 36-50, Jan. 1965.

39. TERRA, A. R. Tração cervical em tratamento ortodôntico. Ortodontia, São Paulo, v. 8 n. 3, p. 227-242, set./dez. 1975

40. TEUSCHER, U. An appraisal of growth and reaction to extraoral anchorage simulation of orthodontic-orthopedic results. Am J Orthod, St. Louis, v. 89, p.113-121, Feb. 1986.

41. TONDELLI, P. M.; BAGGIO, P. E. A utilização de implantes como ancoragem em Ortodontia: revisão da literatura. Ortodontia Gaúcha, Porto Alegre, v. 7, n. 2, jul/dez. 2003.

42. TULLOCH, J. F. C.; PHILLIPS, C.; KOCH, G.; PROFFIT, W. R. The effect of early intervention on skeletal pattern in class II malocclusion: a randomized clinical trial. Am J Orthod, v.111, no. 4, p. 391-400, Apr. 1997

43. TULLOCH, J. F. C.; PROFFIT, W. R.; PHILLIPS, C. Influences on the outcome of early treatment for class II malocclusion. Am J Orthod, St. Louis, v. 111, no. 5, p. 391-400, May 1997.

44. ÜÇEM, T.T.; YÜKSEL, S. Effects of different vectors of forces applied by combined headgear. Am J Orthod, St. Louis, v. 113, no. 3, p. 316-323, Mar. 1998.

45. WHEELER, T. T. et. al. Effectiveness of early treatment of Class II malocclusion. Am J Orthod, St. Louis, v. 121, no.1, p. 9-17, Jan. 2002.

46. WIESLANDER, L.; BUCK, D. L. Physiologic recovery after cervical traction therapy. Am J Orthod, St. Louis, v. 66, no. 3, p. 294-301, Sept. 1974.

\section{Endereço para correspondência}

Roberto Hideo Shimizu

Rua Padre Anchieta, 1846 - Conj. 602/3/4

Champagnat

Curitiba - PR.

E-mail: robertoshimizu@yahoo.com.br 